\title{
Seeds and the City: The
} Interdependence of Zoochory and Ecosystem Dynamics in Urban Environments

\author{
Tiziana A. Gelmi-Candusso ${ }^{\text {1* }}$ and Anni M. Hämäläinen ${ }^{2,3+}$ \\ 1 Department of Behavioral Ecology and Sociobiology, German Primate Center-Leibniz-Institut für Primatenforschung, \\ Göttingen, Germany, ${ }^{2}$ School of Optometry, University of Montreal, Montreal, QC, Canada, ${ }^{3}$ Department of Ecology and \\ Genetics, University of Oulu, Oulu, Finland
}

\section{OPEN ACCESS}

Edited by:

Casper H. A. Van Leeuwen,

Netherlands Institute of Ecology

(NIOO-KNAW), Netherlands

Reviewed by:

Joanna Czarnecka,

Maria Curie-Skłodowska University,

Poland

Bianca Lopez,

National Socio-Environmental

Synthesis Center (SESYNC),

United States

*Correspondence:

Tiziana A. Gelmi-Candusso

tgelmi-candusso@dpz.eu orcid.org/0000-0003-0990-5255

${ }^{\dagger}$ Anni M. Hämäläinen orcid.org/0000-0001-9260-8299

Specialty section:

This article was submitted to Biogeography and Macroecology,

a section of the journal

Frontiers in Ecology and Evolution

Received: 21 September 2018

Accepted: 04 February 2019

Published: 05 March 2019

Citation:

Gelmi-Candusso TA and Hämäläinen AM (2019) Seeds and the

City: The Interdependence of Zoochory and Ecosystem Dynamics in Urban Environments.

Front. Ecol. Evol. 7:41. doi: 10.3389/fevo.2019.00041
The increasing urban sprawl has contributed to the extensive fragmentation and reduction of natural habitat worldwide. Urbanization has a range of adverse effects on ecosystem functioning, including the disruption of plant dispersal processes across the landscape. Urban fragmentation can alter the distance and directionality of dispersal, leading to disrupted gene flow among populations. The dispersal processes of plants that rely on animal-mediated dispersal (zoochory) may be disproportionately affected by urbanization, as many animals avoid urban areas or restrict their movements within urban habitats. This could alter the efficiency of animal dispersal vectors and modify seed movements across urban habitats. While recent studies suggest that seed dispersal networks can be complex and dynamic even in highly managed green areas with relatively low biodiversity, zoochory in urban environments remains understudied. We synthesize the existing literature on zoochory in urban environments and place the findings in the context of ecosystem dynamics. We assess the ecological and evolutionary consequences for seed dispersal, following urbanization, by considering how zoochory is affected by specific features of urban environments. These include the complexity of habitats with varying continuity; high disturbance and intense management; a high proportion of alien species combined with low natural biodiversity; animal behavioral adjustments in different urban settings; and rapid evolutionary change due to urbanization. We conclude that (1) urbanization can disrupt and alter zoochory processes; and (2) successful zoochory can, in turn, alleviate or worsen the challenges to ecosystem dynamics originating from increased urbanization. The dynamic urban seed dispersal networks are emerging as useful models for the adaptability of seed dispersal communities. Their study can also shed light on eco-evolutionary processes under anthropogenic selective pressures, including species interactions. Finally, urban zoochory processes are critical to the functioning of urban ecosystems and as such, constitute an important ecosystem service with management implications. We propose directions for further research into urban zoochory processes to ensure the maintenance of ecosystem dynamics as urbanization continues.

Keywords: urban seed dispersal, anthropogenic disturbance, animal behavior, local adaptation, altered communities, urban evolution, urbanization, urban animal communities 


\section{INTRODUCTION}

Anthropogenic disturbance (see Glossary) is becoming the norm for most of the world's flora and fauna. Already half of the terrestrial surface has been altered by humans (Vitousek et al., 2008; Hooke and Martín-Duque, 2012). A major ongoing trend is increasing urbanization among human populations, with cities around the world growing in number and size (Grimm et al., 2008). The urban environment is a unique ecosystem characterized by fragmentation, patchiness, various forms and degrees of disturbance, and alien species (Rebele, 1994). The accompanying changes in community assemblages and increased selective pressures can have pivotal effects on mutualisms, such as animal-mediated seed dispersal, a key process in maintaining ecosystem dynamics and biodiversity (Richardson et al., 2000). To characterize and predict the consequences of urbanization on seed dispersal, it is necessary to examine the broad effects of urbanization on plant and animal communities and their interactions. We attempt to do so by focusing on the effects of three specific features of the urban environment: fragmented habitat mosaic, altered community composition, and the associated adaptations of urban populations.

Evidence from natural environments indicates that seed dispersal by animals (i.e., zoochory) is influenced by anthropogenic disturbances, such as habitat fragmentation, habitat loss and hunting. For example, a decline in animal disperser abundance can alter seed removal rates (Markl et al., 2012), and human activity and fragmentation can lead to changes in disperser movement patterns (Fernández-Juricic and Tellería, 2000; Ciuti et al., 2012; Leblond et al., 2013; Preisler et al., 2013; Cote et al., 2017; Emer et al., 2018; Gaynor et al., 2018). Such changes, in turn, influence seed dispersal patterns and scale (Westcott and Graham, 2000). In urban environments, disrupted seed dispersal may result in interrupted gene flow, and the isolation of small populations of zoochorous plants (Harris et al., 2016; Johnson and Munshi-South, 2017; Schilthuizen, 2018), with cascading consequences for the functioning of the ecosystem.

The types of anthropogenic disturbance in natural habitats (fragmentation, patchiness, and habitat degradation) are partially shared with urban environments. However, some disturbances are specific to urban environments. For example, as opposed to logging and hunting, urban disturbance includes direct management and arrangement of vegetation, and severe structural disturbance created by urban infrastructure. Thus, while many of the general effects of disturbance and fragmentation are expected to be similar between urban habitats and disturbed natural environments, the dispersal outcomes also depend on the distinct features of urban environments.

In the complex, fragmented, urban habitat mosaic, ecologically different green patches with their various taxa are exposed to each other in ways that would not occur in nature (Lepczyk et al., 2017). Urban communities typically differ from the surrounding natural habitats in species richness and abundance, community assemblages and species interactions (Rebele, 1994; Kowarik, 1995; Rolando et al., 1997; McKinney, 2006, 2008; Markl et al., 2012; Fontúrbel et al., 2015). While native species richness declines (Liang et al., 2008; McKinney, 2008; Faeth et al., 2011; Young et al., 2016), many alien species are introduced and interact with local communities (Rebele, 1994; Alberti et al., 2017). These patterns are characteristic enough that urban ecosystems are more similar to each other than to their surrounding natural landscapes (McKinney, 2006). Strong selective pressures generated by the same urban features frequently lead to rapid behavioral, phenotypic (Alberti et al., 2017) and genetic changes (Cheptou et al., 2008; Smith and Bernatchez, 2008; Harris et al., 2016; Gorton et al., 2018) in animal and plant species, reinforcing the unique ecosystem profile of urban environments. Seed dispersal has been indicated as a critical factor in driving assembly patterns of urban plant communities (Johnson et al., 2018), and is integral in connecting urban green habitats with one another and with the surrounding landscape (Culley et al., 2007). Seed dispersal by humans has been examined in detail (Wichmann et al., 2009; Auffret, 2011; Bullock et al., 2018) especially in urban habitats (von der Lippe and Kowarik, 2008, 2012; von der Lippe et al., 2013), however, animal seed dispersal in urban environments remains understudied.

To evaluate the overall effects of urbanization on zoochory, we synthesize the empirical research on urban zoochory and place the findings in the context of similar processes observed in natural and rural, human-altered environments. We discuss the ecological and evolutionary consequences for seed dispersal following urbanization by considering how zoochory is affected by three defining characteristics of urban environments: (1) a landscape mosaic characterized by habitat complexity, disturbance and fragmentation, (2) an altered plant and animal community composition; and (3) genetic and phenotypic adjustments of plants and animals to the urban environment. We then identify knowledge gaps in the study of urban zoochory. Finally, we propose ways in which knowledge of urban zoochory processes can be used in urban planning and as models for universal zoochory processes.

\section{SEED DISPERSAL IN THE URBAN MOSAIC}

Nearly all urban areas are landscape mosaics containing patches of vegetation arranged with varying degrees of connectedness in a highly fragmented matrix of built environment. Patches of vegetation include a wide range of highly diverse habitat types with a diverse level of disturbance, ranging from nearly pristine urban forests to managed garden flowerbeds and including cracks in the walls of buildings (Francis and Chadwick, 2013). The habitat patches are connected within the urban matrix by corridors, such as railway networks, ravines, and small green areas acting as stepping stones. Together, diverse vegetation patches, corridors and the matrix of built environment form the urban mosaic (sensu the patch-corridormatrix model; Forman, 1995). The consequences of the mosaic on the success of seed dispersal by animals are 2-fold: first, a 
TABLE 1 | Effects of habitat complexity on urban zoochory and vice versa.

\begin{tabular}{|c|c|c|c|c|c|c|c|}
\hline $\begin{array}{l}\text { Aspect of zoochory } \\
\text { affected by altered } \\
\text { urban habitat }\end{array}$ & $\begin{array}{l}\text { Type of } \\
\text { zoochory }\end{array}$ & Animal focus & Plant focus & $\begin{array}{l}\text { City } \\
\text { size }^{b}\end{array}$ & $\begin{array}{l}\text { Country } \\
\left(\text { continent }{ }^{\mathrm{c}}\right)\end{array}$ & Region & References \\
\hline $\begin{array}{l}\text { Altered dispersal } \\
\text { pattern/increased distance }\end{array}$ & $E$ & Birds (various) & Phoradendron affine & $\mathrm{L}$ & Brazil (SA) & TR & $\begin{array}{l}\text { Kiyoshi Maruyama } \\
\text { et al., } 2012\end{array}$ \\
\hline $\begin{array}{l}\text { Colonization/regeneration of } \\
\text { disturbed habitat }\end{array}$ & $E$ & Birds (various) & Various & $X L$ & USA (NA) & $\mathrm{TE}$ & $\begin{array}{l}\text { Robinson and Handel, } \\
2000\end{array}$ \\
\hline $\begin{array}{l}\text { Disrupted dispersal } \\
\text { across barrier (road) }\end{array}$ & $S$ & $\begin{array}{l}\text { Birds (Garrulus glandarius), } \\
\text { terrestrial mammals } \\
\text { (Niviventer confucianus) }\end{array}$ & Quercus chenii & $X L$ & China (AS) & TE & Niu et al., 2018 \\
\hline \multirow{2}{*}{$\begin{array}{l}\text { Effective } \\
\text { removal/transportation of } \\
\text { viable seeds of multiple } \\
\text { species }\end{array}$} & $E$ & $\begin{array}{l}\text { Terrestrial mammals (Vulpes } \\
\text { vulpes) }\end{array}$ & Various & $X L$ & Belgium (EU) & TE & \\
\hline & $S$ & $\begin{array}{l}\text { BIRDS (Garrulus glandarius), } \\
\text { terrestrial mammals } \\
\text { (Niviventer confucianus) }\end{array}$ & Quercus chenii & $X L$ & China (AS) & TE & Niu et al., 2018 \\
\hline \multirow{2}{*}{$\begin{array}{l}\text { Effective } \\
\text { removal/transportation of } \\
\text { viable seeds of multiple } \\
\text { species in discontinuous } \\
\text { habitat }\end{array}$} & $E$ & Birds (Turdus spp.) & Various & S & Brazil (SA) & TR & $\begin{array}{l}\text { Gasperin and Pizo, } \\
2009\end{array}$ \\
\hline & $E, S$ & Bats (Cynopterus brachiolis) & Various & $X L$ & Malaysia (AS) & TR & Tan et al., 2000 \\
\hline \multirow[t]{5}{*}{$\begin{array}{l}\text { Maintaining connectivity in } \\
\text { discontinuous habitat }\end{array}$} & $E$ & $\begin{array}{l}\text { Terrestrial mammals (Vulpes } \\
\text { vulpes) }\end{array}$ & Various & S & Spain (EU) & $\mathrm{TE}$ & Cancio et al., 2017 \\
\hline & $E$ & Birds (various) & Cabralea canjerana & $\mathrm{L}$ & Brazil (SA) & TR & Pizo, 1997 \\
\hline & $S$ & Birds (Garrulus glandarius) & $\begin{array}{l}\text { Quercus robur and } \\
\text { Quercus petrea }\end{array}$ & $\mathrm{L}$ & Sweden (EU) & TE & Hougner et al., 2006 \\
\hline & $S$ & Birds (Garrulus glandarius) & $\begin{array}{l}\text { Quercus robur and } \\
\text { Quercus petrea }\end{array}$ & $\mathrm{L}$ & Sweden (EU) & TE & Lundberg et al., 2008 \\
\hline & $S$ & $\begin{array}{l}\text { Terrestrial mammals (Sciurus } \\
\text { carolinensis) }\end{array}$ & Quercus rubra & S & USA (NA) & TE & Steele et al., 2011 \\
\hline $\begin{array}{l}\text { Maintaining seed } \\
\text { removal/dispersal in } \\
\text { fragmented habitat }\end{array}$ & $\begin{array}{l}\text { assumed: } \\
E, S\end{array}$ & Unknown & Ferocactus wislizeni & $\mathrm{L}$ & USA (NA) & $\mathrm{TE}$ & Ness et al., 2016 \\
\hline
\end{tabular}

a Type of zoochory: E, endozoochory; M, myrmecochory; S, synzoochory.

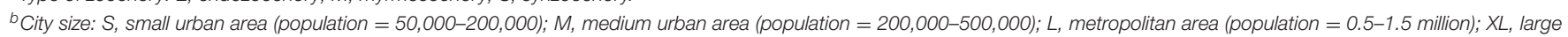
metropolitan area (population $\geq 1.5$ million) (OECD, 2018).

${ }^{c}$ Continent: AU, Australia, EU, Europe; NA, North America; SA, South America.

higher diversity of habitats may increase the diversity of seed dispersers (Melles et al., 2003; Ossola et al., 2015). Second, the movement of seed dispersers within the matrix depends on the resource distribution among patches (Dunning et al., 1992) and their connectivity (Taylor et al., 1993). Empirical evidence on the effects of the urban mosaic on zoochory processes is summarized in Tables 1, 2 (see also sections Urban Communities and Species Interactions, and Adaptations of Animals to Urbanization and Consequences to Zoochory). In this section, we first describe how the features of the discontinuous habitat mosaic may disrupt seed disperser movements and further restrict seed movement between habitat patches. Then, we discuss evidence of the contrary, i.e., how animal dispersers may increase the connectivity of plant populations despite habitat discontinuity.

\section{Urban Disturbance and Fragmentation May Disrupt Seed Movement by Animal Dispersers}

Empirical studies have found evidence that habitat degeneration, disturbance and fragmentation alter the seed movements of zoochorous plants. The changes appear to operate through shifts in the disperser community and behavior, with edge preference or avoidance playing a potentially important role (e.g., Levey et al., 2008; Warren et al., 2015; see sections Urban Communities, and Species Interactions and Adaptations of Animals to Urbanization and Consequences to Zoochory). For example, roads surrounding a forest patch were found to act as a movement barrier for scatter hoarders, effectively constraining seed movements to the fragment (Niu et al., 2018). This concurs with findings from non-urban (Asensio et al., 2017) and urban 
TABLE 2 | Effects of altered communities on urban zoochory.

\begin{tabular}{|c|c|c|c|c|c|c|c|}
\hline $\begin{array}{l}\text { Aspect of zoochory } \\
\text { affected by altered } \\
\text { urban community }\end{array}$ & $\begin{array}{l}\text { Type of } \\
\text { zoochory }\end{array}$ & Animal focus & Plant focus & $\begin{array}{l}\text { City } \\
\text { size }^{b}\end{array}$ & $\begin{array}{l}\text { Country } \\
\left(\text { continent }{ }^{c}\right)\end{array}$ & Region & Reference \\
\hline $\begin{array}{l}\text { Effective } \\
\text { removal/transportation of } \\
\text { viable seeds of multiple } \\
\text { species }\end{array}$ & $E$ & $\begin{array}{l}\text { Terrestrial mammals } \\
\text { (Didelphis albiventris) }\end{array}$ & Various & $X L$ & Brazil (SA) & TR & Cáceres et al., 1999 \\
\hline $\begin{array}{l}\text { Higher effectiveness of } \\
\text { removal/transportation of } \\
\text { viable seeds by remaining } \\
\text { species in community }\end{array}$ & M & Ants (various) & Viola pubescens & L & Canada (NA) & TE & $\begin{array}{l}\text { Thompson and } \\
\text { McLachlan, } 2007\end{array}$ \\
\hline $\begin{array}{l}\text { Secondary disperser } \\
\text { effectively replaced primary } \\
\text { vector/change in zoochory } \\
\text { type }\end{array}$ & $S$ & $\begin{array}{l}\text { Terrestrial mammals } \\
\text { (Dasyprocta leporina) }\end{array}$ & $\begin{array}{l}\text { Astrocaryum } \\
\text { aculeatissimum }\end{array}$ & $X L$ & Brazil (SA) & TR & $\begin{array}{l}\text { Zucaratto and dos } \\
\text { Santos Pires, } 2015\end{array}$ \\
\hline \multirow[t]{3}{*}{$\begin{array}{l}\text { Spread of alien plant } \\
\text { species }\end{array}$} & $E$ & $\begin{array}{l}\text { Terrestrial mammals (Vulpes } \\
\text { vulpes) }\end{array}$ & Various & $X L$ & Belgium (EU) & TE & D'hondt, 2011 \\
\hline & $E$ & Birds (various) & Various & S & Portugal (EU) & TE & Cruz et al., 2013 \\
\hline & M & Ants (Linepithema humile) & $\begin{array}{l}\text { Acacia sophorae, } A \text {. } \\
\text { retinodes, Polygala } \\
\text { myrtifolia, Dipogon } \\
\text { lignosus }\end{array}$ & $X L$ & Australia (AU) & TE & $\begin{array}{l}\text { Rowles and O'Dowd, } \\
2009\end{array}$ \\
\hline
\end{tabular}

a Type of zoochory: E, endozoochory; M, myrmecochory; S, synzoochory.

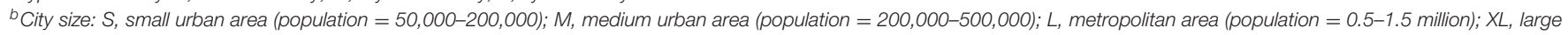
metropolitan area (population $\geq 1.5$ million) (OECD, 2018).

${ }^{c}$ Continent: AU, Australia; EU, Europe; NA, North America; SA, South America.

areas (Fey et al., 2016; Johnson et al., 2017) that roads restrict animal movements enhancing the fragmentation and isolation of urban green patches, and further delineating the habitat mosaic. Smaller, more isolated, fragments tend to support fewer animal disperser species and smaller population sizes in urban areas (Srbek-Araujo et al., 2017), leading to lower fruit removal rates, as found for cactus fruit removal rates by mammals (Ness et al., 2016). If small, isolated fragments are avoided by animals, it is also likely that seed influx into isolated fragments may decline, eventually leading to local extirpation of certain plant species.

\section{The Role of Seed Dispersers in Maintaining the Integrity of the Urban Mosaic}

Although animal dispersers are influenced by urban disturbance and fragmentation, an increasing number of studies suggest that dispersers play an important role in buffering the adverse effects of habitat alteration by increasing the regeneration and connectivity of urban green areas (Table 1).
Seed Dispersers Can Influence Habitat Regeneration Animal dispersers play a key role in the regeneration of urban degraded habitats (Robinson and Handel, 2000; Lundberg et al., 2008) by influencing the influx rate of seeds from source areas. For example, seed dispersal by jays is estimated to result in the recruitment of more than 33,000 saplings per year in a large urban park, representing a significant ecosystem service and reducing the level of habitat disturbance within the urban park (Hougner et al., 2006). Generally, however, it seems that animal seed dispersers contribute to the influx of seeds into disturbed areas mainly after regeneration has already started through other dispersal means (wind dispersal, seed banks). This was suggested by the finding that plants with predominantly zoochorous traits were found in larger and older urban forest fragments (Jesus et al., 2012) and older vacant lots (Knapp et al., 2016; Neuenkamp et al., 2016; Johnson et al., 2018), while anemochorous traits were predominant in smaller and recent fragments (see section Effects of Urbanization on the Community Composition of Plants for further details on plant community 
composition). Likely, as heterogeneity of a degenerated habitat (e.g., cleared lots) increases, areas become more suitable for animal movement, increasing the influx of animal-dispersed seeds and the incidence of zoochorous plants recruited. This is concordant with previous findings in tropical forest restoration where heterogeneity of a habitat attracted seed dispersers to sites in regeneration (Wunderle, 1997), and where tree density (Zapata et al., 2014) and availability of perching sites (González-Varo et al., 2017a) increased visitation rates of disturbed areas.

\section{Seed Dispersers May Maintain Habitat Connectivity and Reduce Habitat Disturbance}

In addition to regeneration, animal dispersers can help maintain plant populations by facilitating seed exchange between habitat patches. Potential animal habitat connectors in the complex urban mosaic are either animals with differential habitat use for their daily activities (Lundberg et al., 2008; Gasperin and Pizo, 2009) or animals with long travel distances that can move through disturbed habitats (Cancio et al., 2017); see also section Consequences of Changes in Movement Patterns of Urban Dispersers on Seed Movement. An example of increased connectivity due to differential habitat use are urban thrushes, which eat fruits predominantly in open areas of cities (e.g., gardens and streets) but use forests for nesting and shelter, connecting these two differently disturbed green patches and increasing seed influx from forests into cities (Gasperin and Pizo, 2012; Da Silveira et al., 2016). These birds were also found to visit multiple forest fragments, showing these also play a role in the functional connectivity between forest fragments. Similarly, Eurasian Jays in Stockholm use different forest types for different purposes (i.e., oak stands for feeding/caching; coniferous stands for breeding), therefore coniferous forests in between oak stands function as stepping stones, enhancing connectivity between oak stands (Lundberg et al., 2008). Red foxes, prevalent and well-adapted in many urban areas, can move across disturbed areas, which can increase connectivity when dispersing in fragmented areas, as in the Mediterranean peninsula, where red foxes are able to move through differently disturbed areas, connecting remnants of the threatened keystone habitat. However, connectivity was limited to fragments separated by a distance smaller than the foxes' territory (Cancio et al., 2017). Therefore, we can expect connectivity by animal dispersers to be determined by the distance between urban fragments relative to the animals' movement ranges. Where the distances between fragments and remnant seed sources are beyond the usual seed dispersal distance of available seed dispersers, wildlife corridors can enhance connectivity (Beier and Noss, 1998; Chetkiewicz et al., 2006).

\section{URBAN COMMUNITIES AND SPECIES INTERACTIONS}

Plant and animal communities in urban areas differ greatly from natural environments. The expansion of impervious surface in urban areas reduces habitable areas, while landscape management structurally simplifies the vegetation within these.
A small number of habitable areas with simplified vegetation supports fewer species, reducing species richness (McKinney, 2008). However, other factors present in urban areas can instead increase species richness and population densities, such as high habitat heterogeneity, high primary productivity and food availability, and a high influx of alien species (Baker and Harris, 2007; McKinney, 2008; Šálek et al., 2015). Changes in species richness and abundance may considerably influence the ecosystem service provided by the local seed dispersal network. Therefore, it is critical to examine changes in communities to understand the effects of urbanization on the maintenance of plant population connectivity and extinction risk in urban areas. In this section, we describe how human activity within urban areas affects plant and animal communities, and how changes within these affect zoochory.

\section{Effects of Urbanization on the Community Composition of Plants}

Plant species diversity increases with urbanization up to intermediate levels of urbanization but decreases again at very high levels of urbanization (at least in temperate regions; McKinney, 2008). Furthermore, studies of urban plant communities suggest a pattern of increasing proportions of primarily animal-dispersed plants in more urbanized areas (Knapp et al., 2008; Burton et al., 2009; Marco et al., 2010). The general prevalence of plants depending on zoochory could be partially explained by the finding that animal-dispersed plants can have a lower risk of local extinction at more urbanized sites (Williams et al., 2005). With a higher proportion of animaldispersed plants, animal seed dispersers play an important role in maintaining or modifying plant communities in urban areas (see section Effects of Altered Communities on Urban Seed Dispersal). However, the pattern of increased presence of animaldispersed plants in urbanized areas is not universal (Thompson and McCarthy, 2008). and fine-scale differences may exist in the predominant type of zoochory present along the rural-urban gradient. For example, Albrecht and Haider (2013) found a high prevalence of synzoochorous plant species in urban areas in contrast to a trend toward more myrmecochorous species in the surrounding rural areas. Deciphering why these systems differ from the general trend presents an interesting direction for future research.

Urban communities also differ from the surrounding environments through their higher proportion of alien plant species (Kowarik, 1995; Kühn and Klotz, 2006). A large number and abundance of alien plant species have been found in soil seed banks in urban forests (Overdyck and Clarkson, 2012) and in urban ornamental gardens (Marco et al., 2010; Reichard, 2010). While most alien plant species are introduced intentionally (e.g., in gardens), they spread unintentionally through urban areas, primarily via zoochory (Padayachee et al., 2017). These urban populations of alien plants (especially species dispersed by birds Gosper et al., 2005; Gaggini et al., 2017; can then act as seed sources for surrounding forests, leading to ecological consequences beyond the urban habitat. The spread of alien plant species to surrounding pristine environments can even be 
amplified by the interaction of multiple dispersers. In Poland, the increase in abundance of rooks made the alien Eurasian walnuts from human settlements available to natural forest dispersers, Jays (Garrulus glandarius). The jays removed the high number of acorns that rooks had cached in rural areas and further distributed them into the surrounding forests (Lenda et al., 2018). Therefore, understanding the complete dispersal network and multi-phase dispersal in urban areas is key in managing the expansion of zoochorous alien plant species.

\section{Effects of Urbanization on the Community Composition and Abundance of Animal Dispersers}

Seed disperser abundance and species richness are both affected by urbanization through modification and reduction of available habitats (Larsen et al., 2005; Collen et al., 2014; Dirzo et al., 2014; Pimm et al., 2014); negative interactions with humans (Koch and Barnosky, 2006; Tregidgo et al., 2017); human infrastructure (Loss et al., 2015); and vehicles (Laurance et al., 2009). Animal species richness tends to decline with increasing urbanization level (McKinney, 2008) independently of the type of vegetation present (Faeth et al., 2011). The total abundance of dispersers, on the other hand, depends on the population dynamics of each disperser species and the surrounding urban environment. Population size can be strongly reduced in urban habitats as seen for birds in an urban forest fragment, where only half as many birds were present relative to pristine areas (Pizo, 1997). Disperser abundance may also be higher in urban areas if disperser species or populations are especially successful, as seen for opportunistic, urban-adapted species, such as Eastern gray squirrels (Steele et al., 2011) and red foxes (Šálek et al., 2015). The number and species array of the animals that are available as dispersers thus result from the composition of the urban animal community and population processes of those species.

\section{Effects of Altered Communities on Urban Seed Dispersal}

Empirical studies have found evidence of successful maintenance of urban seed dispersal in spite of altered species composition. However, we can expect a diverse array of effects on seed dispersal after community alterations, depending on the composition of the plant and animal communities, and the interactions between them (Table 2).

\section{Consequences of Defaunation and Functional Replacement of Seed Dispersers on Zoochory}

The effectiveness of zoochory is influenced by the local abundance of animal individuals capable of dispersing seeds, as well as the assemblage of disperser species. Disperser abundance and assembly may affect the number of seeds dispersed, the diversity of seed species dispersed, their specific deposition sites, and whether they germinate. Defaunation combined with the higher plant diversity in urban areas (McKinney, 2008) can lead to a situation where a larger number of plant species is dispersed by a smaller number of animal species, with potential consequences in terms of competition between dispersers.
Defaunation will specifically influence disperser abundance, with consequences for the number of seeds dispersed. However, changes in population densities can also influence intraand inter-specific interactions between dispersers, ultimately influencing the dispersers' feeding and post-feeding behavior (see section Behavioral Responses of Urban Dispersers to Humans and Other Animals Have Consequences for Seed Dispersal). These behaviors, in turn, result in altered seed dispersal distances and patterns, as commonly happens in natural habitats (McConkey and O'Farrill, 2016).

Following defaunation, functional replacement of lost animals may occur, where a new species takes on the functional role (e.g., as seed disperser) of a species lost from the area. When the exclusive seed disperser is extirpated and not replaced functionally by other species, then the recruitment of plant species that rely on that disperser will completely subside. The absence of animal-dispersed plant species from otherwise suitable urban habitats (i.e., secondary urban forests) would suggest such seed dispersal failure (Tsang and Corlett, 2005). The local extinction of a seed disperser might be particularly disruptive in fragmented landscapes (Rodríguez-Cabal et al., 2007), such as urban areas, since animal species richness may be reduced and fragment isolation may limit disperser replacement by animals from other fragments. Nonetheless, very few plant-disperser associations are strictly obligate (Richardson et al., 2000), hence dynamic changes in dispersal networks rather than extinctions are generally predicted.

The significance of the changes in the community assemblage on dispersal effectiveness depends on the degree of functional equivalence of the primary and novel species as dispersers. When functional replacement is incomplete, i.e., seed dispersal by the animals that take the place of a lost primary disperser differs from the original dispersal service, the strongest effects on zoochory may be seen. Such effects in urban environments are poorly understood, but evidence from natural areas suggest community changes can lead to differences in dispersal effectiveness (Schupp, 1993; Uriarte et al., 2011; Schupp et al., 2017). This is because seed dispersal distance, removal rate, and seed processing are all taxon-dependent, ultimately altering the total seed shadow and recruitment success of dispersed plants (Martínez et al., 2008). First, novel disperser species may have different morphological characteristics than the primary disperser, such as gape constraints (Pizo, 1997) or body size (Ness et al., 2004; Carbone et al., 2005; Young et al., 2016), that limit their feeding or movement ranges, ultimately influencing seed dispersal distance. Second, disperser species consume different food resources leading to differences in the seed rain they contribute to in terms of species diversity and richness. For example, the recent higher abundance of rooks in urban areas of Poland transport a high number of seeds with low species diversity (primarily of weeds and ruderal species), from rural areas to urban areas, contributing to the homogenization of plant biodiversity in urban areas (Czarnecka et al., 2013). Novel dispersers may also have different feeding behavior. For example, novel dispersers in an urban forest fragment differed from the primary disperser community by feeding more on the forest ground but regurgitating seeds also in urban areas. The consequences of this were that despite the 
loss of some seeds from the forest area, an influx of natural seed species into urban green patches was created (Pizo, 1997). Third, plant recruitment may depend on the disperser assemblage when germination success differs among disperser species, such as for urban mistletoes (Kiyoshi Maruyama et al., 2012). Germination success may decline if seeds that are originally adapted to be dispersed by other taxa are damaged by gut passage through novel or secondary disperser species, such as bird- and lizarddispersed seeds when processed by mammals (Nogales et al., 2005). Finally, the loss of a specific seed disperser species may even increase seed dispersal effectiveness by relieving interspecific resource competition, potentially allowing dispersal by other, competitively weaker, urban species. When those species are more efficient foragers, the loss of a primary disperser may lead to increased seed removal rates (Thompson and McLachlan, 2007; see also Mahandran et al., 2018). However, the impact of such changes on plant recruitment success remains poorly studied.

When the novel dispersers fully functionally replace a lost local disperser, seed movements are unaffected. For example, the loss of agoutis in an urban forest fragment showed no effects on seed dispersal distance, likely due to a fully functional replacement by other rodents (Zucaratto and dos Santos Pires, 2015).

\section{Consequences of Alien Animal Species on Native Plant Dispersal Success}

Introduced animal species necessarily lead to novel species interactions, which may alter seed dispersal and recruitment of native plant species by displacing native dispersers or by predating on native seeds. Displacement of native dispersers has been seen in the coastal shrub along Melbourne, Australia, by the invasive argentine ants (Linepithema humile). These removed fewer seeds of the native plant species Acacia retinoide and buried seeds of another native plant Acacia sophorae closer to the source plant, reducing seed dispersal distance (Rowles and O'Dowd, 2009). Predation of native seeds by introduced animal dispersers has been seen for mammals and ants. For example, introduced mammals compromise the success of artificially planted native seeds in regeneration procedures (Overdyck et al., 2013). Similarly, introduced ant species that are common in urban areas commonly act as predators of native seeds species, leaving seeds unburied or consuming elaiosomes but discarding seeds beneath the source (Ness et al., 2004). Therefore, the outcome for the plant populations depends on how these processes by alien animals compare to the functions of the native dispersers, and the overall effects of the novel animal community on seed dispersal and seed predation.

\section{Consequences of Alien Plant Species on Urban Dispersal Networks}

Introduced plants may alter seed dispersal networks in urban areas by competing with native plants for seed dispersal services. The effects of alien competition with native plants for seed dispersal services in urban areas will depend on the attractiveness of their diaspores to seed dispersers (Aslan and Rejmanek, 2012; see also section Consequences of Dietary Changes of Urban
Seed Dispersers on Seed Rain). For example, the invasive antdispersed South African shrub Polygala myrtifolia outcompeted native plant species for seed dispersal services by ants (Rowles and O'Dowd, 2009). However, competition for seed dispersal services may not necessarily result in negative outcomes for native species if these benefit from the additional dispersers brought into the area by the resources provided by alien plant species (van Leeuwen, 2018).

Alien plant species can also have cascading effects on urban seed dispersers by modifying the habitat. For example, weed invasions may lead to alterations in the ant disperser community, potentially changing the seed removal rates of both alien and native species (Grimbacher and Hughes, 2002). The overall effects of alien plant species on the ecosystem thus depend on the direct competition with native species for dispersal services and the indirect effects on local dispersers through modification of the environment. However, their success in competition with local species will influence their invasive potential within urban areas and beyond.

\section{ADAPTATIONS OF ANIMALS TO URBANIZATION AND CONSEQUENCES TO ZOOCHORY}

There is increasing evidence that features of the urban environment cause rapid evolutionary change in urban plants and animals (Alberti et al., 2017; Rivkin et al., 2018). Selective pressures in urban areas include human presence, the heat island effect (Brans et al., 2017, 2018), changes in food and material resources, higher toxin concentrations than in natural environments (Johnson and Munshi-South, 2017), and the already discussed habitat disturbance and fragmentation (section Seed Dispersal in the Urban Mosaic). Furthermore, changes in the community and the associated mutualistic species interactions could also act as a selective pressure for species within the network. Evolutionary change results from the general effects of such selective pressures, combined with genetic drift, reduced gene flow, and bottleneck effects due to small, isolated populations (Alberti et al., 2017). Rapid adaptations, as well as non-adaptive changes, lead to declining genetic diversity within urban populations, while genetic differentiation between urban populations increases (Johnson and MunshiSouth, 2017). The consequences for zoochory processes depend on whether the plant and disperser coevolve in a way that mutualistic relationships are retained. Nonetheless, even when mutualistic relationships are retained, seed dispersal efficacy of animals - dispersal distance, microhabitat of deposition sites, and germination success - can all be affected when animals adjust their behavioral, movement and dietary patterns in response to urbanization.

\section{Behavioral Responses of Urban Dispersers to Humans and Other Animals Have Consequences for Seed Dispersal}

Urban vertebrates tend to express more bold and explorative behaviors (Prosser et al., 2006; Martin and Réale, 2008; Evans 
et al., 2010; Uchida et al., 2016), less vigilance (Chapman et al., 2012), and even lower stress response to human proximity (Sol et al., 2018; Weaver et al., 2018) than conspecifics in rural environments. Evidence from urban and rural blackbird populations suggest changes in behavior could be genetically determined and heritable, as genetic divergence was found for a gene associated with harm avoidance (Mueller et al., 2013). Despite such evidence of increased tolerance to human presence, many studies have also observed increased avoidance-related behaviors. Diurnal animals might become more active at night (Gaynor et al., 2018) or animals might alter their movement ranges (Tracey et al., 2013; Tucker et al., 2018) and feeding patterns (Fernández-Juricic and Tellería, 2000) when exposed to human activity. Changes in intra- and inter-specific interactions, and predation risk created by urbanization may change disperser behavior, e.g. foraging behavior (McConkey and O'Farrill, 2016) altering seed dispersal processes within the urban environments.

Intra- and interspecific competition can specifically influence behaviors with consequences for seed dispersal effectiveness. For example, the population density of flying foxes on small islands in Tonga was positively associated with dispersal distances due to changes in intra-specific competition (McConkey and Drake, 2006). At low densities, the bats appear to feed in situ and drop seeds under the parent tree, whereas at high densities, to avoid aggressive interactions in the fruiting trees, they transported the fruit to feed elsewhere, increasing seed dispersal distances (Richards, 1990). A similar phenomenon was also observed in three bat species of a suburban habitat in India (Mahandran et al., 2018). The largest bat species, which consumed overall more fruits, often consumed fruit in situ leading to short seed dispersal distances, and when intraspecific aggressions arose, they had longer seed dispersal distances. Dispersal effectiveness by smaller bat species was also apparently influenced by the avoidance of interspecific competition, as they typically carried fruit away to a feeding roost at varying distances from the parental tree. Another example of the effect of interspecific interactions on seed dispersal patterns is peri-urban eastern gray squirrels (Sciurus carolinensis), which modified their choice of caching sites in response to the presence of potential competitors (Steele et al., 2015).

\section{Consequences of Changes in Movement Patterns of Urban Dispersers on Seed Movement}

Urban areas have been associated with changes in average animal movement distances, with potential consequences for seed dispersal distances. Shorter movements are generally observed in areas affected by humans, likely due to reduced habitat availability or higher local food availability that reduces the need to travel long distances to forage (Tucker et al., 2018). However, the effect of urban areas on movement patterns varies according to the scale of measurement, as urbanization affects animal movement patterns on multiple scales within and beyond urban areas.

At the scale of habitat patches, habitat preference and avoidance of open areas may influence seed movement. For example, preference for nesting in forest interiors by ants in exurban areas, changed ant movement away from forest edges, changing seed dispersal directionality and leading to a reduced presence of ant-dispersed woodland herbs on forest edges (Warren et al., 2015). Scatter hoarders had faster seed removal rates and shorter dispersal distances along forest edges due to edge avoidance (Niu et al., 2018). Seed movement at the scale of habitat patches may be affected more at a higher urbanization degree with stronger fragmentation, smaller fragment sizes and greater edge proportion (see also section Seed Dispersal in the Urban Mosaic).

At an inter-patch level, the discontinuity of suitable habitat in the urban mosaic could also lead to increased seed dispersal distances in species with home ranges larger than the typical patch size. For example, reduced availability of foraging and roosting areas increased the distance between core areas used by mallards, resulting in longer-distance seed dispersal (Kleyheeg et al., 2017). The study was not restricted to urban sites, but the processes likely apply also to urban areas as mallards are common inhabitants of urban parks. Dispersal between patches may be facilitated by corridors with vegetation favoring disperser movement. For example, the linear distribution of host trees of bird-dispersed mistletoe Phoradendron affine, artificially planted along roadsides, may change directionality of seed dispersers (e.g., Euphonia chlorotica) and increase seed dispersal distance as opposed to rural areas, where host trees were naturally distributed in clumps (Kiyoshi Maruyama et al., 2012). Research from agricultural areas shows the clearance of vegetation along roads may also result in longer seed dispersal distances by ants (Palfi et al., 2017). Therefore, management of vegetation along roadsides may be key in managing urban seed dispersal.

At a larger scale, some migratory urban birds showed a decline in migratory tendencies (Partecke and Gwinner, 2007) and others showed anticipation of migratory movements in urban areas due to the heat island effect (Tryjanowski et al., 2013). As migration is one of the mechanisms for long-distance dispersal, shifts in migration could substantially influence the "long tail" of seed shadows for dispersed plant species.

\section{Consequences of Dietary Changes of Urban Seed Dispersers on Seed Rain}

The altered community structures, including the high abundance of alien plant species, and the availability of anthropogenic food items may induce shifts in the diets of urban dispersers, with potential effects on the diversity and richness of seeds dispersed. A preference for alien species has been observed in red foxes in certain areas (Cancio et al., 2017); in gray squirrels dispersing seeds at an urban cemetery (Thompson and Thompson, 1980); and in the argentine ant (Linepithema humile), which preferred seeds of the invasive South African shrub Polygala myrtifolia (Rowles and O'Dowd, 2009). In this case, body size of ant dispersers in relationship to diaspore size may be an important determinant of their differential preference between diaspores of native and alien plants (Gorb and Gorb, 1995). In fact, in Sydney, Australia, invasive fruit species with similar seed size as native species were removed by ants at a similar rate (Grimbacher 
and Hughes, 2002). Seeds of a large number of native and alien species have been observed in the scats of urban canids, viverrids, and mustelids (Tsang and Corlett, 2005; Corlett, 2011; D'hondt, 2011; Tsuji et al., 2011; Cancio et al., 2017), suggesting that omnivorous predators are also important dispersers in urban areas. A disperser preference for alien plants may also disrupt the dispersal of some native species (Bermejo and Guitian, 2000; López-Bao and González-Varo, 2011; Rost et al., 2012), by dispersing alien seeds instead of native seeds.

The abundance of food items from garbage in urban areas and other artificial sources of food, such as bird feeders, can also modify the diets of seed dispersers, in particular for opportunistic frugivores, ultimately influencing seed rain in terms of species richness and abundance. For example, regurgitated pellets of urban rooks contained mostly seeds from fleshy fruits, thought to result from higher consumption of garbage in urban areas, since pellets of rural rooks contained mostly seeds from dryfruits (Kitowski et al., 2017). The diet of red foxes contained more fruits and berries from anthropogenic sources (i.e., garbage and orchards) in urban areas than in peri-urban areas (Contesse et al., 2004) potentially influencing dispersed species richness in different areas. Finally, evidence of a preference for bird feeders can be seen by changes in beak morphology of an urban population of finches in Tucson, USA, directionally selected toward larger sizes as a result of the advantage provided by bird feeders which contain larger and harder seeds than natural seeds in the surrounding habitat (Badyaev et al., 2008). Bird feeders may therefore potentially influence seed shadows created by birds. When behavioral and morphological changes in animals lead to a more frequent dispersal of some types of seeds at the expense of others, it may, in turn, serve as a selective pressure for the plants that rely on zoochory for their dispersal.

\section{POTENTIAL EVOLUTIONARY CHANGES IN PLANTS IN RESPONSE TO ALTERED SEED DISPERSAL}

Plant species might adapt to the novel dispersal challenges via changes to their seed or fruit morphology or even phenology. Diaspore characteristics, including dispersal mode, appears to be a relatively flexible construct that represents a continuum rather than a discrete trait, and as such, is amenable to relatively rapid evolutionary change (Vander Wall and Longland, 2004; Forget et al., 2005; Cheptou et al., 2008; Galetti et al., 2013). In evidence of such processes, a gradual reduction in palm seed size has been observed in fragmented tropical forests where large-gaped frugivores have been lost (Galetti et al., 2013), and similar changes may be predicted in urban areas where body size of birds has been reduced (Battisti and Dodaro, 2016). We are aware of no research demonstrating evolutionary responses of urban plants to changes in animal-mediated dispersal. The potential for rapid evolutionary change due to urbanization has, however, been demonstrated in wind-dispersing plants. Cheptou et al. (2008) found that seed size of holy hawkbeard (Crepis sancta) evolved in urban areas to favor a morph adapted to short-distance dispersal over a wind-dispersed morph that disperses over longer distances. Later research suggested the differentiation in the life history of the plant may be due to higher isolation of subpopulations within the urban environment (Dubois and Cheptou, 2017).

Other studies have identified relevant changes in plant life history in urban areas, such as changes in fecundity, growth rate and phenology (Brans et al., 2018). In commongarden experiments, seeds of Virginia pepperweed (Lepidium virginicum) from urban populations produced more seeds than those collected from rural populations. Furthermore, plants from urban populations were phenotypically and genetically more homogenous than those from rural populations (Yakub and Tiffin, 2017). More general evidence of the adaptive potential of fecundity was demonstrated by Thompson and McCarthy (2008) who found heavier seeds to predict higher success in native plants within urban habitats. Interestingly, this relationship was the opposite in non-native plants within urban habitats. Plant phenology may also change (possibly due to the "heat island effect"), as suggested by the accelerated germination time and thus earlier flowering of urban common ragweed (Ambrosia artemisiifolia) relative to rural conspecifics (Gorton et al., 2018). The phenology and fecundity of certain species within urban environments can alter resource availability and distribution for seed dispersers, which in turn might influence the abundance and effectiveness of those animals as dispersers. Together, these findings suggest a strong potential for plants to adapt to challenges posed by features of the urban environment, possibly including adaptive responses to the changes in the communities and behaviors of their dispersers.

\section{DISCUSSION}

The reviewed literature shows strong evidence of interdependence between urban zoochory and broader ecosystem dynamics. Given the predominance of animaldispersed plants in urban areas (Knapp et al., 2008; Burton et al., 2009; Marco et al., 2010). zoochory is integral in sustaining urban vegetation patches. As such, zoochory represents an important ecosystem function in urban areas, but its success relies on the adaptability and effectiveness of the animal dispersers that themselves inhabit a disturbed, fragmented environment. The literature we reviewed highlighted a range of consequences, limitations, and side effects of the disperser community composition and behavior on seed dispersal in the urban mosaic, as well as their interdependence with the surrounding environment (Figure 1):

1. Urbanization alters various aspects of zoochory (Figure 1, black continuous arrows).

a. Fragmentation and degradation lead to changes in the abundance, movement, and diets of dispersers, with concurrent changes in inter-specific interactions and seed predation All of these have consequent effects on seed dispersal patterns (see sections Seed Dispersal in the Urban Mosaic, and Adaptations of Animals to Urbanization and Consequences to Zoochory). 


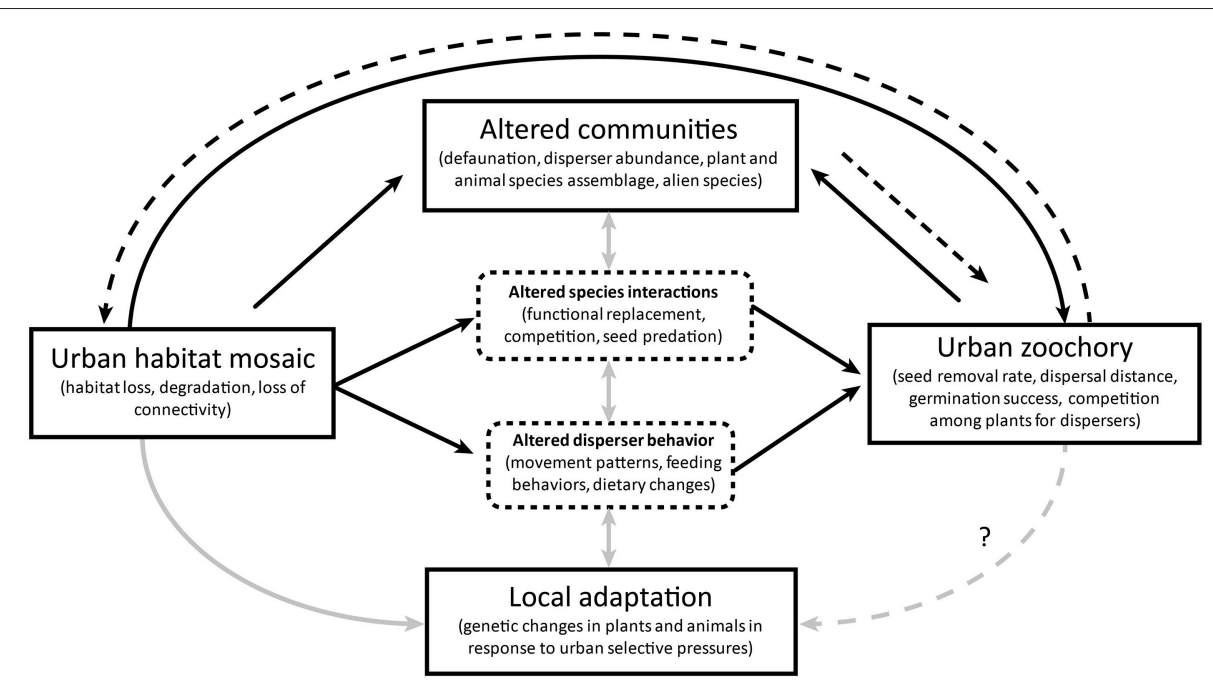

FIGURE 1 | Interdependence between zoochory processes and the urban ecosystems. The urban effects of an altered habitat on zoochory may be direct (e.g., by influencing the abundance of dispersers or their success) or mediated through changes in seed disperser behaviors and novel species interactions (black continuous lines). In turn, seed dispersers shape urban vegetation within the mosaic, strengthening or weakening the processes within the urban habitat (black dashed lines). Complex interactions exist between the urban plant and animal networks, disperser behaviors, and local adaptations of populations in the urban habitat mosaic (gray continuous lines). Zoochory also has the potential to directly influence local adaptations if it acts as a selective pressure. Plant dispersal outcomes and ecosystem dynamics are thus linked to zoochory processes in urban areas.

b. Dispersed plant communities and disperser communities are altered through habitat loss, defaunation, and a high presence of alien species. These changes influence the abundance of individuals and assemblage of species available to form mutualistic relationships and maintain functioning dispersal networks. Presence of alien animal species may also influence levels of seed predation, influencing germination success. In addition, the availability and potentially higher attractiveness of alien plants to dispersers may increase the competition for dispersal services between native and alien plants, leading to further selective pressures for plant dispersal (see section Urban Communities and Species Interactions).

c. Strong selective pressures and small, fractioned populations, lead to urban evolution and phenotypic adjustments in both dispersed plants and animal disperser species. If such changes are adaptive, they can improve the persistence of a species in the urban environment but could disrupt pre-existing seed dispersal processes if the plants and their dispersers do not co-adapt successfully (Figure 1, gray arrows) (see sections Adaptations of Animals to Urbanization and Consequences to Zoochory, and Potential Evolutionary Changes in Plants in Response to Altered Seed Dispersal).

2. Animal seed dispersal feeds back into the ecosystem dynamics by shaping the urban environment (Figure 1, black dashed arrows).

a. Animal seed dispersal in urban areas plays a fundamental role in connecting habitat patches, contributing to the regeneration of degraded habitats, and maintaining the renewal of plant populations within green areas. These may even sustain directional dispersal into suitable habitats within the degraded and patchy urban mosaic (see section Seed Dispersal in the Urban Mosaic).

b. Zoochory can also be detrimental for local communities, promoting the spread of potentially invasive alien species through urban areas and even toward surrounding natural habitats (see sections Urban Communities and Species Interactions, and Adaptations of Animals to Urbanization and Consequences to Zoochory).

Because of the complex interrelationships between urban plants, dispersers, and their surrounding landscape, the molding of urban dispersal networks and zoochory processes in cities can vary among systems. However, research on urban zoochory to date has focused on a fairly small number of study systems (Tables 1, 2). Most of the reviewed research focused on seed dispersal by birds and terrestrial mammals in big cities ( $>0.5$ million inhabitants) in the temperate region of the Northern Hemisphere, therefore potentially representing relatively simple seed dispersal networks. Despite the complexity of seed dispersal systems, the patterns of interdependence between zoochory and ecosystem dynamics we have discussed should apply across systems. The relative strength and importance of the different associations may vary. The effects of urbanization on seed dispersal depend on how the local dispersers react to urbanization, but also on whether changes in one dispersal interaction are compensated for or further disrupted by other actors in the urban species community. 
Research into these complexities has only begun but presents unsurpassed opportunities for better understanding fundamental zoochory processes, examining changes in species interactions in anthropogenically altered environments; and maintaining essential urban ecosystem services on an increasingly urbanized planet. Below, we will identify the current most significant gaps in the research, propose actions to address these open questions, and present evidence for the potential gains from investing in systematic research on urban zoochory.

\section{Future Directions}

So far, empirical investigations of urban zoochory have primarily been restricted to observational studies of seed dispersal processes and seed removal experiments. While such studies can provide a useful starting point, they alone cannot address the more complex mechanisms operating in urban zoochory networks. We identify some of the most pressing open questions in the field and suggest approaches to proceed in addressing them.

\section{From Focusing on Single Interactions Toward Understanding Networks}

Understanding plant-animal seed dispersal interactions of urban areas in a community context is necessary to draw valid conclusions about evolutionary and ecological processes (Vázquez et al., 2009). However, future studies should move beyond the examination of specific interactions between a small number of plants and their dispersers and aim to examine entire seed dispersal networks. So far, only one study has comprehensively analyzed seed dispersal networks of birds in an urban park (Cruz et al., 2013). Since different dispersers in the network can affect overall seed dispersal effectiveness differently according to their diet and movement patterns (Mello et al., 2011; Correa et al., 2016), analyzing seed dispersal networks can give a sense of the robustness of the community. Also, seed dispersal networks can describe seed dispersal connectivity within the landscape mosaic better than single animal-plant interactions given the versatility of seed dispersal interactions (Timóteo et al., 2018). Network nestedness and modularity (i.e., number of interactions and distribution of links), level of redundancy of the links, and dietary specialization of dispersers can all provide information on the resilience and robustness of the community (Burgos et al., 2007; Bastolla et al., 2009; McConkey and Drake, 2015). In tropical seed dispersal networks, higher plant diversity and lower fruit abundance (in fragmented landscapes) have been related to less specialized seed dispersal networks (Schleuning et al., 2012; Chama et al., 2013), and we would expect a similar pattern in urban areas. Furthermore, urbanization could be affecting the redundancy of interactions, by altering disperser abundance and habitat use (Blendinger, 2017).

The study of seed dispersal networks in urban areas would benefit from methods commonly used to track seed movements in natural areas, such as genetic barcoding of disperser species from fecal matter remaining on dispersed seeds (González-Varo et al., 2014), color-coding for identification of seeds in fecal samples (González-Varo et al., 2017b), or maternal identification of seed coats and seedlings through microsatellite genotyping (Godoy and Jordano, 2001; Smouse et al., 2012).

\section{From Urban Forests Toward Understanding Connectivity Within Cities and Beyond}

To complement the existing research, more information is needed on the functional connection through seed dispersal between urban areas and the surrounding natural areas, and between different habitats within the urban mosaic. Urban areas can be major barriers for plant dispersal at the landscape level, disrupting gene flow from one side of an urban area to the other. However, most studies to date have focused on seed dispersal within urban forests, leaving out seed dispersal across the urban matrix. Therefore, little is still known about the movement of seeds and dispersers among the different habitats within the urban mosaic, or about the magnitude of dispersal disruption across the wider landscape due to urban barriers. Furthermore, the proximity and quality of the surrounding environment probably influence biodiversity within green urban patches, but this possibility has yet to be examined. A better understanding of seed flow between urban habitats and across urbanized areas can inform management measures on how to better sustain natural seed dispersal processes, to reduce the spread of invasive species, or increase the regeneration rate of degraded areas and vacant lots.

To analyze connectivity within and across cities, plant movements and community changes across large distances should be examined. A possible approach would be the combined use of landscape genetics methods (Machon et al., 2003; Manel and Holderegger, 2013; Miles et al., 2018) and extensive observational or experimental approaches estimating seed dispersal patterns (Kiyoshi Maruyama et al., 2012; Kleyheeg et al., 2017). To analyze regeneration of degraded habitats, useful approaches include examining spatio-temporal succession or recolonization of severely degraded areas, such as vacant lots (Johnson, 2015; Johnson et al., 2018) or of former landfills (Robinson and Handel, 2000).

\section{From Observing Urban Fragmentation Toward Understanding Its Evolutionary Consequences}

The consequences of isolation of populations within fragmented urban landscapes on urban zoochory processes have barely been examined. However, the extreme fragmentation of urban habitats is one of the reasons to expect genetic changes in urban populations, and thus also the potential for plant-disperser coadaptations. Further research on the effects of isolation in urban communities is needed to understand whether urban movement barriers can influence adaptation rates of plants, dispersers, and plant-disperser co-adaptations. On one hand, isolation can enhance the rate of local adaptation by disrupting gene flow, and thus may also allow for more rapid co-adaptations of plants and their short-distance dispersers. On the other hand, isolated populations are more susceptible to local extirpation, and any long-distance dispersal could even have negative effects through outbreeding depression (Johnson and Munshi-South, 2017). Most of what we know so far in terms of local adaptation in urban areas is for wind-dispersed species. Wind-dispersed plants 
with alternative dispersal morphs can show a tendency toward one morph in fragmented urban environments vs. continuous populations, leading to adaptation over generations (Cheptou et al., 2008). Furthermore, in such dispersal mode, roads can counteract isolation by acting as corridors for long dispersal events (Kowarik and von der Lippe, 2011). We are not aware of any studies demonstrating local adaptation to animal-mediated dispersal due to urbanization, despite its high representation in urban areas. If animal movement is restricted, local adaptation should be enhanced (Arendt, 2015), as evidence shows limited seed exchange can create high population substructure and provide the opportunity for divergence through genetic drift (Twyford et al., 2014). Furthermore, changes in inter-specific competition between dispersers, created by urbanization, may also promote rapid evolution (Hart et al., 2018). However, pollen dispersal may compensate for gene flow restriction by seed dispersal (Scheepens et al., 2012) and should not be overlooked when estimating genetic connectivity.

Local adaptation has been successfully examined with common-garden experiments (Kawecki and Ebert, 2004; Cheptou et al., 2008) and landscape community genomics (Hand et al., 2015). Prospective methods to analyze genetic differentiation in isolated areas within cities include nextgeneration genomic tools (Sork, 2016) combined with improved statistical approaches examining spatial distributions (Safner et al., 2011; Renner et al., 2016).

\section{From Patterns of Seed Rain Toward Patterns of Regeneration}

Finally, animal-mediated seed dispersal dynamics were often conjectured from plant distributions or seed banks in combination with the most likely primary dispersal mode of the species present. However, the final location of most seeds is a result of more than one dispersal mode or vector (Ozinga et al., 2004). In the fine-scale mosaic of microhabitat suitability of highly managed and disturbed sites, recruitment success may be significantly influenced by the fine-scale movements of seeds by invertebrates. So far, few studies have analyzed microscale processes by invertebrates and of other secondary seed dispersal vectors influencing recruitment success. In the seed dispersal literature in general, and in urban areas in particular, there is a pressing need to better account for seed fates and the contribution of different dispersal vectors to recruitment success (Vander Wall and Longland, 2004; Forget et al., 2005; Hämäläinen et al., 2017). The estimation of seed dispersal effectiveness (Schupp, 1993; Schupp et al., 2017) without knowledge of plant recruitment is of limited use for predicting plant distributions and evolutionary responses.

Models that incorporate all relevant aspects of the dispersal process from seed removal to post-dispersal events across different landscape features would be valuable for the analysis of effective seed dispersal networks, by-passing shortcomings of interpretations created by excluding recruitment success (Kleyheeg et al., 2017). Recruitment success may also be included into the study of seed dispersal networks by analyzing seedling distribution (Donoso et al., 2016) or parentage analysis of seedlings (Ismail et al., 2017).

\section{Managing Urban Zoochory as an Ecosystem Service}

Given the integral role of seed dispersal in maintaining ecosystem dynamics in cities and functional connectivity within and across cities, understanding urban seed dispersal should become a priority for urban management strategies. Connectivity between urban green areas could be improved by retaining pockets of natural vegetation (Lepczyk et al., 2017), developing a greenway network of backyards habitats and planted boulevards (Rudd et al., 2002), and creating wildlife corridors, such as linear transportation structures, e.g., railroads (Penone et al., 2012), soft linear developments (Suárez-Esteban et al., 2013), forest-like environments (Da Silveira et al., 2016) and high canopy areas (González-Varo et al., 2017a). Minimally managed parks that foster various stages of ecological progression, permit animal movements and maintain long-distance dispersal, could additionally help maintain diversity within the plant communities. Even small protected areas within cities can serve as seed sources of a large number of plant species for surrounding areas (Dyderski et al., 2017). Studying the influence of urbanization on seed dispersal networks of keystone native species, such as the significant role of Eurasian jays in the dispersal of oaks, and that of red foxes in the dispersal of Jujube (Ziziphus lotus) (Lundberg et al., 2008; Cancio et al., 2017), would be of particular interest in terms of the maintenance of remnant vegetation. The manipulation of seed disperser movement patterns (Gosper et al., 2005), for example by enhancing existing infrastructures or improving habitat structural connectivity (Beninde et al., 2015), could prove effective in achieving these management goals.

Efforts to sustain seed dispersal networks are valuable not only because they sustain ecosystems, but also because the maintenance of ecosystem services, such as seed dispersal can have substantial economic value. For example, the sustained oak regeneration by Eurasian jays in Stockholm city has been valued at $\$ 2,100-\$ 9,400$ per hectare annually, based on the estimated cost of manually planting an equal number of oaks (Hougner et al., 2006). Combined with the benefits of urban biodiversity for human health and quality of life (Jackson, 2003; Tzoulas et al., 2007), conserving urban seed dispersal networks should be considered a key component in the planning of sustainable cities and surrounding environments. The value of sustaining functional ecosystems is critical to biodiversity and human wellbeing, and its value increases in significance as habitat alterations and climate change place pressure on diaspore movement across the landscape.

\section{Urban Dispersal Networks as a Model for Seed Dispersal Dynamics}

The complexity of urban communities and habitats, their novel interspecific interactions and phenotypic changes of plants and animals can lead to very dynamic seed dispersal networks. Common characteristics of urban environments, such as increased anthropogenic pressure, fragmentation and edge effects, prevalence of invasive organisms, and commonality of local extinctions, mirror some of the most 
widespread threats to ecosystems across landscapes (Sundriyal and Sharma, 1996; Wright, 2005; Portugal et al., 2016; Grizzetti et al., 2017). Therefore, urban development serves as an exceptional, easily accessible, and replicated experiment that can yield important insights into eco-evolutionary processes under such threats (McDonnell and Pickett, 1990; Johnson and Munshi-South, 2017; Rivkin et al., 2018).

First, the highly variable urban environment, with its "unnatural" species assemblages and altered communities, can create novel dispersal interactions via replacement of lost primary dispersers with functionally similar native or alien species that are more tolerant of the urban environment (Blendinger, 2017; section Effects of Altered Communities on Urban Seed Dispersal). The study of such functional replacements can provide ways to examine the evolution of species interactions and the adaptability of communities to changing environments.

Second, an improved understanding of seed dispersal processes in fragmented and degraded urban settings could be further used to understand the movement of zoochorous plants across diverse landscapes under similar degradation conditions at different spatial scales, for example under loss of natural habitat or climate change. Such information can be used to predict the range expansion of animal-dispersed plants, with particular relevance for distribution modeling under climate change scenarios.

Third, urbanization has been referred to as "the best and largest-scale unintended evolution experiment" (Johnson and Munshi-South, 2017) because of the rapid evolutionary change observed in numerous organisms across thousands of cities around the world. This replicated experiment offers opportunities for large-scale, coordinated comparative studies. Such goals might be accomplished by making use of unexplored methods in zoochory research, such as standardization of data collection protocols and citizen science. A promising example of

\section{REFERENCES}

Alberti, M., Correa, C., Marzluff, J. M., Hendry, A. P., Palkovacs, E. P., Gotanda, K. M., et al. (2017). Global urban signatures of phenotypic change in animal and plant populations. Proc. Natl. Acad. Sci. U.S.A. 114:201606034. doi: $10.1073 /$ pnas. 1606034114

Albrecht, H., and Haider, S. (2013). Species diversity and life history traits in calcareous grasslands vary along an urbanization gradient. Biodivers. Conserv. 22, 2243-2267. doi: 10.1007/s10531-013-0437-0

Arendt, J. D. (2015). Effects of dispersal plasticity on population divergence and speciation. Heredity (Edinb). 115, 306-311. doi: 10.1038/hdy.2015.21

Asensio, N., Murillo-Chacon, E., Schaffner, C. M., and Aureli, F. (2017). The effect of roads on spider monkeys' home range and mobility in a heterogeneous regenerating forest. Biotropica 49, 546-554. doi: 10.1111/btp.12441

Aslan, C., and Rejmanek, M. (2012). Native fruit traits may mediate dispersal competition between native and non-native plants. NeoBiota 12, 1-24. doi: $10.3897 /$ neobiota. 12.2357

Auffret, A. G. (2011). Can seed dispersal by human activity play a useful role for the conservation of European grasslands? Appl. Veg. Sci. 14, 291-303. doi: 10.1111/j.1654-109X.2011.01124.x

Badyaev, A. V., Young, R. L., Oh, K. P., and Addison, C. (2008). Evolution on a local scale: developmental, functional, and genetic bases of divergence in bill form such large-scale efforts is the ongoing Global Urban Evolution Project on the evolution of white clover (Trifolium repens) (Thompson et al., 2016). While the study of species coevolution due to urbanization is only beginning, seed dispersal interactions are a promising target for increasing our understanding of urban coevolution and the consequent adaptability of communities.

\section{CONCLUSIONS}

Animal-mediated seed dispersal in urban environments is, unquestionably, understudied. Given the explosive growth of urban habitat worldwide, the urgency of facilitating vital ecosystem processes in increasingly anthropogenic environments, and the central role of zoochory in maintaining such processes in cities, there is much to be gained from more systemic research on urban zoochory. The easy accessibility of cities, the improving techniques that facilitate increasingly elegant designs, and the availability of testable hypotheses based on theoretical foundations, should make urban zoochory an increasingly valuable field of research.

\section{AUTHOR CONTRIBUTIONS}

TAG-C and AMH contributed equally to the conception of the presented idea, the analysis of the literature, and the writing of the manuscript. Both authors revised and approved the final version.

\section{ACKNOWLEDGMENTS}

We thank Casper Van Leeuwen for the invitation to contribute to this research topic, Omer Nevo, and the two reviewers for the insightful comments that helped improve the manuscript, and the Leibniz-Institut and Deutsches Primatenzentrum for financing the open-access publication through the Leibniz Association's Open Access Publishing Fund. and associated changes in song structure between adjacent habitats. Evolution 62, 1951-1964. doi: 10.1111/j.1558-5646.2008.00428.x

Baker, P. J., and Harris, S. (2007). Urban mammals: what does the future hold? An analysis of the factors affecting patterns of use of residential gardens in Great Britain. Mamm. Rev. 37, 297-315. doi: 10.1111/j.1365-2907.2007.00102.x

Bastolla, U., Fortuna, M. A., Pascual-García, A., Ferrera, A., Luque, B., and Bascompte, J. (2009). The architecture of mutualistic networks minimizes competition and increases biodiversity. Nature 458, 1018-1020. doi: 10.1038 /nature07950

Battisti, C., and Dodaro, G. (2016). Mapping bird assemblages in a mediterranean urban park: evidence for a shift in dominance towards medium-large body sized species after 26 years. Belgian J. Zool. 146, 81-89. Available online at: http://biblio.naturalsciences.be/associated_publications/bjz/146-2/ bjz_146_2_battisti-p81-89.pdf

Beier, P., and Noss, R. F. (1998). Do Habitat corridors provide connectivity? Conserv. Biol. 12, 1241-1252. doi: 10.1046/j.1523-1739.1998.98036.x

Beninde, J., Veith, M., and Hochkirch, A. (2015). Biodiversity in cities needs space: a meta-analysis of factors determining intra-urban biodiversity variation. Ecol. Lett. 18, 581-592. doi: 10.1111/ele.12427

Bermejo, T., and Guitian, J. (2000). Fruit consumption by foxes and martens in NW Spain in autumn: a comparison of natural and agricultural areas. Folia Zool. 49, 89-92. Available online at: https://www.researchgate.net/publication/ 
292641620_Fruit_consumption_by_foxes_and_martens_in_NW_Spain_in_ autumn_A_comparison_of_natural_and_agricultural_areas/citations

Blendinger, P. G. (2017). Functional equivalence in seed dispersal effectiveness of Podocarpus parlatorei in Andean fruit-eating bird assemblages. Front. Ecol. Evol. 5:57. doi: 10.3389/fevo.2017.00057

Brans, K. I., Engelen, J. M. T., Souffreau, C., and De Meester, L. (2018). Urban hot-tubs: Local urbanization has profound effects on average and extreme temperatures in ponds. Landsc. Urban Plan. 176, 22-29. doi: 10.1016/j.landurbplan.2018.03.013

Brans, K. I., Jansen, M., Vanoverbeke, J., Tüzün, N., Stoks, R., and De Meester, L. (2017). The heat is on: Genetic adaptation to urbanization mediated by thermal tolerance and body size. Glob. Chang. Biol. 23, 5218-5227. doi: $10.1111 /$ gcb.13784

Bullock, J. M., Bonte, D., Pufal, G., da Silva Carvalho, C., Chapman, D. S., García, C., et al. (2018). Human-mediated dispersal and the rewiring of spatial networks. Trends Ecol. Evol. 33, 958-970. doi: 10.1016/j.tree.2018.09.008

Burgos, E., Ceva, H., Perazzo, R. P., Devoto, M., Medan, D., Zimmermann, M., et al. (2007). Why nestedness in mutualistic networks? J. Theor. Biol. 249, 307-313. doi: 10.1016/j.jtbi.2007.07.030

Burton, M. L., Samuelson, L. J., and Mackenzie, M. D. (2009). Riparian woody plant traits across an urban-rural land use gradient and implications for watershed function with urbanization. Landsc. Urban Plan. 90, 42-55. doi: 10.1016/j.landurbplan.2008.10.005

Cáceres, N. C., Dittrich, V. A. O., and Monteiro-Filho, E. L. A. (1999). Fruit consumption, distance of seed dispersal and germination of Solanaceaous plants ingested by common opossum (Didelphis aurita) in Southern Brazil. Rev. d'Ècol. 54, 225-234.

Cancio, I., González-Robles, A., Bastida, J. M., Isla, J., Manzaneda, A. J., Salido, T., et al. (2017). Landscape degradation affects red fox (Vulpes vulpes) diet and its ecosystem services in the threatened Ziziphus lotus scrubland habitats of semiarid Spain. J. Arid Environ. 145, 24-34. doi: 10.1016/j.jaridenv.2017.05.004

Carbone, C., Cowlishaw, G., Isaac, N. J., and Rowcliffe, J. M. (2005). How far do animals go? Determinants of day range in mammals. Am. Nat. 165, 290-297. doi: $10.1086 / 426790$

Chama, L., Berens, D. G., Downs, C. T., and Farwig, N. (2013). Habitat characteristics of forest fragments determine specialisation of plantfrugivore networks in a mosaic forest landscape. PLOS ONE 8:e54956. doi: 10.1371/journal.pone.0054956

Chapman, T., Rymer, T., and Pillay, N. (2012). Behavioural correlates of urbanisation in the cape ground squirrel Xerus inauris. Naturwissenschaften 99, 893-902. doi: 10.1007/s00114-012-0971-8

Cheptou, P.-O., Carrue, O., Rouifed, S., and Cantarel, A. (2008). Rapid evolution of seed dispersal in an urban environment in the weed Crepis sancta. Proc. Natl. Acad. Sci. U.S.A. 105, 3796-3799. doi: 10.1073/pnas.0708446105

Chetkiewicz, C.-L. B., St. Clair, C. C., and Boyce, M. S. (2006). Corridors for conservation: integrating pattern and process. Annu. Rev. Ecol. Evol. Syst. 37, 317-342. doi: 10.1146/annurev.ecolsys.37.091305.110050

Ciuti, S., Muhly, T. B., Paton, D. G., McDevitt, A. D., Musiani, M., and Boyce, M. S. (2012). Human selection of elk behavioural traits in a landscape of fear. Proc. R. Soc. B Biol. Sci. 279, 4407-4416. doi: 10.1098/rspb. 2012.1483

Collen, B., Whitton, F., Dyer, E. E., Baillie, J. E., Cumberlidge, N., Darwall, W. R., et al. (2014). Global patterns of freshwater species diversity, threat and endemism. Glob. Ecol. Biogeogr. 23, 40-51. doi: 10.1111/geb. 12096

Contesse, P., Hegglin, D., Gloor, S., Bontadina, F., and Deplazes, P. (2004). The diet of urban foxes (Vulpes vulpes) and the availability of anthropogenic food in the city of Zurich, Switzerland. Mamm. Biol. Zeitschr. Säugetierkd. 69, 81-95. doi: 10.1078/1616-5047-00123

Corlett, R. T. (2011). How to be a frugivore (in a changing world). Acta Oecol. 37, 674-681. doi: 10.1016/j.actao.2011.01.005

Correa, S. B., Arujo, J. K., Penha, J., Nunes Da Cunha, C., Bobier, K. E., and Anderson, J. T. (2016). Stability and generalization in seed dispersal networks: a case study of frugivorous fish in Neotropical wetlands. Proc. R. Soc. B Biol. Sci. 283, 1-9. doi: 10.1098/rspb.2016.1267

Cote, J., Bestion, E., Jacob, S., Travis, J., Legrand, D., and Baguette, M. (2017). Evolution of dispersal strategies and dispersal syndromes in fragmented landscapes. Ecography 40, 56-73. doi: 10.1111/ecog.02538
Cruz, J. C., Ramos, J. A., da Silva, L. P., Tenreiro, P. Q., and Heleno, R. H. (2013). Seed dispersal networks in an urban novel ecosystem. Eur. J. For. Res. 132, 887-897. doi: 10.1007/s10342-013-0722-1

Culley, T. M., Sbita, S. J., and Wick, A. (2007). Population genetic effects of urban habitat fragmentation in the perennial herb Viola pubescens (Violaceae) using ISSR markers. Ann. Bot. 100, 91-100. doi: 10.1093/aob/mcm077

Czarnecka, J., Kitowski, I., Sugier, P., Mirski, P., Krupinski, D., and Pitucha, G. (2013). Seed dispersal in urban green space - does the rook Corvus frugilegus L. contribute to urban flora homogenization? Urban For. Urban Green. 12, 359-366. doi: 10.1016/j.ufug.2013.03.007

Da Silveira, N. S., Niebuhr, B. B., Muylaert, R., de, L., Ribeiro, M. C., and Pizo, M. A. (2016). Effects of land cover on the movement of frugivorous birds in a heterogeneous landscape. PLoS ONE 11:e0156688. doi: 10.1371/journal.pone.0156688

D'hondt, B. (2011). Scat analysis reveals a wide set of plant species to be potentially dispersed by foxes. Plant Ecol. Evol. 144, 106-110. doi: $10.5091 /$ plecevo.2011.472

Dirzo, R., Young, H. S., Galetti, M., Ceballos, G., Isaac, N. J., and Collen, B. (2014). Defaunation in the anthropocene. Science 345, 401-406. doi: 10.1126/science.1251817

Donoso, I., García, D., Rodríguez-Pérez, J., and Martínez, D. (2016). Incorporating seed fate into plant-frugivore networks increases interaction diversity across plant regeneration stages. Oikos 125, 1762-1771. doi: 10.1111/oik.02509

Dubois, J., and Cheptou, P.-O. (2017). Effects of fragmentation on plant adaptation to urban environments. Philos. Trans. R. Soc. B Biol. Sci. 372:20160038. doi: $10.1098 /$ rstb.2016.0038

Dunning, J. B., Danielson, B. J., and Pulliam, H. R. (1992). Ecological processes that affect populations in complex landscapes. Oikos 65:169. doi: 10.2307/3544901

Dyderski, M. K., Wronska-Pilarek, D., and Jagodzinski, A. M. (2017). Ecological lands for conservation of vascular plant diversity in the urban environment. Urban Ecosyst. 20, 639-650. doi: 10.1007/s11252-016-0625-2

Emer, C., Galetti, M., Pizo, M. A., Guimarães, P. R., Moraes, S., Piratelli, A., et al. (2018). Seed-dispersal interactions in fragmented landscapes-a metanetwork approach. Ecol. Lett. 21, 484-493. doi: 10.1111/ele.12909

Evans, J., Boudreau, K., and Hyman, J. (2010). Behavioural syndromes in urban and rural populations of song sparrows. Ethology 116, 588-595. doi: 10.1111/j.1439-0310.2010.01771.x

Faeth, S. H., Bang, C., and Saari, S. (2011). Urban biodiversity: patterns and mechanisms. Ann. N. Y. Acad. Sci. 1223, 69-81. doi: 10.1111/j.1749-6632.2010.05925.x

Fernández-Juricic, E., and Tellería, J. L. (2000). Effects of human disturbance on spatial and temporal feeding patterns of blackbird Turdus merula in urban parks in madrid, spain. Bird Study 47, 13-21. doi: 10.1080/00063650009461156

Fey, K., Hämäläinen, S., and Selonen, V. (2016). Roads are no barrier for dispersing red squirrels in an urban environment. Behav. Ecol. 27, 741-747. doi: 10.1093/beheco/arv215

Fontúrbel, F. E., Candia, A. B., Malebrán, J., Salazar, D. A., González-Browne, C., and Medel, R. (2015). Meta-analysis of anthropogenic habitat disturbance effects on animal-mediated seed dispersal. Glob. Chang. Biol. 21, 3951-3960. doi: $10.1111 /$ gcb. 13025

Forget, P.-M., Hulme, P. E., Lambert, J. E., and Vander Wall, S. B. (2005). "Seed fate," in Predation, Dispersal, and Seedling Establishment, eds P. M. Forget, J. E. Lambert, P. E. Hulme, and S. B. Vander Wall (Wallingford: CABI).

Forman, R. T. T. (1995). Some general principles of landscape and regional ecology. Landsc. Ecol. 10, 133-142. doi: 10.1007/BF00133027

Francis, R. A., and Chadwick, M. A. (2013). Urban Ecosystems : Understanding the Human Environment. London: Routledge.

Gaggini, L., Rusterholz, H. P., and Baur, B. (2017). Settlements as a source for the spread of non-native plants into central european suburban forests. Acta Oecol. 79, 18-25. doi: 10.1016/j.actao.2016.12.008

Galetti, M., Guevara, R., Côrtes, M. C., Fadini, R., Von Matter, S., Leite, A. B., et al. (2013). Functional extinction of birds drives rapid evolutionary changes in seed size. Science 340, 1086-1090. doi: 10.1126/science. 1233774

Gasperin, G., and Pizo, M. (2012). Passage time of seeds through the guts of frugivorous birds, a first assessment in Brazil. Rev. Bras. Ornitol. 20, 48-51. Available online at: https://www.researchgate.net/publication/286356306_ Passage_time_of_seeds_through_the_guts_of_frugivorous_birds_a_first_ assessment_in_Brazil 
Gasperin, G., and Pizo, M. A. (2009). Frugivory and habitat use by thrushes (Turdus spp.) in a suburban area in south Brazil. Urban Ecosyst. 12, 425-436. doi: 10.1007/s11252-009-0090-2

Gaynor, K. M., Hojnowski, C. E., Carter, N. H., and Brashares, J. S. (2018). The influence of human disturbance on wildlife nocturnality. Science 360, 1232-1235. doi: 10.1126/science.aar7121

Godoy, J. A., and Jordano, P. (2001). Seed dispersal by animal: exact identification of source trees with endocarp DNA microsatellites. Mol Ecol 10, 2275-2283. doi: 10.1046/j.0962-1083.2001.01342.x

González-Varo, J. P., Arroyo, J. M., and Jordano, P. (2014). Who dispersed the seeds? the use of DNA barcoding in frugivory and seed dispersal studies. Methods Ecol. Evol. 5, 806-814. doi: 10.1111/2041-210X.12212

González-Varo, J. P., Carvalho, C. S., Arroyo, J. M., and Jordano, P. (2017a). Unravelling seed dispersal through fragmented landscapes: frugivore species operate unevenly as mobile links. Mol. Ecol. 26, 4309-4321. doi: $10.1111 / \mathrm{mec} .14181$

González-Varo, J. P., López-Bao, J. V., and Guitián, J. (2017b). Seed dispersers help plants to escape global warming. Oikos 126, 1600-1606. doi: 10.1111/oik.04508

Gorb, S. N., and Gorb, E. V. (1995). Removal rates of seeds of five myrmecochorous plants by the Ant Formica polyctena (Hymenoptera: Formicidae). Oikos 73:367. doi: $10.2307 / 3545960$

Gorton, A. J., Moeller, D. A., and Tiffin, P. (2018). Little plant, big city: a test of adaptation to urban environments in common ragweed (Ambrosia artemisiifolia). Proc. Biol. Sci. 285:20180968. doi: 10.1098/rspb.2018.0968

Gosper, C. R., Stansbury, C. D., and Vivian-Smith, G. (2005). Seed dispersal of fleshy-fruited invasive plants by birds: contributing factors and management options. Divers. Distrib. 11, 549-558. doi: 10.1111/j.1366-9516.2005.00195.x

Grimbacher, P. S., and Hughes, L. (2002). Response of ant communities and ant-seed interactions to bush regeneration. Ecol. Manag. Restor. 3, 188-197. doi: 10.1046/j.1442-8903.2002.00112.x

Grimm, N. B., Faeth, S. H., Golubiewski, N. E., Redman, C. L., Wu, J., Bai, X., et al. (2008). Global change and the ecology of cities. Science 319, 756-760. doi: 10.1126/science.1150195

Grizzetti, B., Pistocchi, A., Liquete, C., Udias, A., Bouraoui, F., and Van De Bund, W. (2017). Human pressures and ecological status of European rivers. Sci. Rep. 7, 1-11. doi: 10.1029/2007gb003085

Hämäläinen, A., Broadley, K., Droghini, A., Haines, J. A., Lamb, C. T., Boutin, S., et al. (2017). The ecological significance of secondary seed dispersal by carnivores. Ecosphere 8:e01685. doi: 10.1002/ecs2.1685

Hand, B. K., Lowe, W. H., Kovach, R. P., Muhlfeld, C. C., and Luikart, G. (2015). Landscape community genomics: understanding eco-evolutionary processes in complex environments. Trends Ecol. Evol. 30, 161-168. doi: 10.1016/j.tree.2015.01.005

Harris, S. E., Xue, A. T., Alvarado-Serrano, D., Boehm, J. T., Joseph, T., Hickerson, M. J., et al. (2016). Urbanization shapes the demographic history of a native rodent (the white-footed mouse, Peromyscus leucopus) in New York City. Biol. Lett. 12:20150983. doi: 10.1098/rsbl.2015.0983

Hart, S. P., Turcotte, M. M., and Levine, J. M. (2018). Effects of rapid evolution on species coexistence. Proc. Natl. Acad. Sci. U.S.A. 116, 2112-2117. doi: 10.1073/pnas.1816298116

Hooke, R. L., and Martín-Duque, J. F. (2012). Land transformation by humans: a review. GSA Today 12, 4-10. doi: 10.1130/GSAT151A.1

Hougner, C., Colding, J., and Söderqvist, T. (2006). Economic valuation of a seed dispersal service in the Stockholm National Urban Park, Sweden. Ecol. Econ. 59, 364-374. doi: 10.1016/j.ecolecon.2005.11.007

Ismail, S. A., Ghazoul, J., Ravikanth, G., Kushalappa, C. G., Uma Shaanker, R., and Kettle, C. J. (2017). Evaluating realized seed dispersal across fragmented tropical landscapes: a two-fold approach using parentage analysis and the neighbourhood model. New Phytol. 214, 1307-1316. doi: 10.1111/nph.14427

Jackson, L. E. (2003). The relationship of urban design to human health and condition. Landsc. Urban Plan. 64, 191-200. doi: 10.1016/S0169-2046(02)00230-X

Jesus, F. M., Pivello, V. R., Meirelles, S. T., Franco, G. A. D. C., and Metzger, J. P. (2012). The importance of landscape structure for seed dispersal in rain forest fragments. J. Veg. Sci. 23, 1126-1136. doi: 10.1111/j.1654-1103.2012.01418.x

Johnson, A. (2015). The Ecology of Urban Vacant Lands: HumanMediated Local Versus Regional Control on Plant Community Assembly. University of Maryland, Baltimore County, ProQuest Dissertations
Publishing. Available online at: https://search.proquest.com/openview/ cbc98d9214d91bd7dc4c8fda1659045d/1?pq-origsite $=$ gscholar $\& c b l=18750 \&$ diss $=\mathrm{y}$

Johnson, A. L., Borowy, D., and Swan, C. M. (2018). Land use history and seed dispersal drive divergent plant community assembly patterns in urban vacant lots. J. Appl. Ecol. 55, 451-460. doi: 10.1111/1365-2664.12958

Johnson, C. D., Evans, D., and Jones, D. (2017). Birds and roads: reduced transit for smaller species over roads within an urban environment. Front. Ecol. Evol. 5:36. doi: $10.3389 /$ fevo. 2017.00036

Johnson, M. T. J., and Munshi-South, J. (2017). Evolution of life in urban environments. Science 358:eaam8327. doi: 10.1126/science.aam8327

Kawecki, T. J., and Ebert, D. (2004). Conceptual issues in local adaptation. Ecol. Lett. 7, 1225-1241. doi: 10.1111/j.1461-0248.2004.00684.x

Kitowski, I., Sándor, A. D., Czarnecka, J., and Grzywaczewski, G. (2017). Diet of rooks Corvus frugilegus and potential seed dispersal in urban and agricultural habitats of Romania and Poland. North West. J. Zool. 13, 94-100. Available online at: http://biozoojournals.ro/nwjz/content/v13n1/ nwjz_e161604_Kitowski.pdf

Kiyoshi Maruyama, P., Mendes-Rodrigues, C., Alves-Silva, E., and Cunha, A. F. (2012). Parasites in the neighbourhood: Interactions of the mistletoe Phoradendron affine (Viscaceae) with its dispersers and hosts in urban areas of Brazil. Flora Morphol. Distrib. Funct. Ecol. Plants 207, 768-773. doi: 10.1016/j.flora.2012.08.004

Kleyheeg, E., Treep, J., de Jager, M., Nolet, B. A., and Soons, M. B. (2017). Seed dispersal distributions resulting from landscape-dependent daily movement behaviour of a key vector species, Anas platyrhynchos. J. Ecol. 105, 1279-1289. doi: 10.1111/1365-2745.12738

Knapp, S., Kühn, I., Wittig, R., Ozinga, W. A., Poschlod, P., and Klotz, S. (2008). Urbanization causes shifts in species' trait state frequencies. Preslia 80, 375-388. Available online at: http://citeseerx.ist.psu.edu/viewdoc/download?doi=10.1.1. $329.8377 \&$ rep $=$ rep $1 \&$ type $=$ pdf

Knapp, S., Stadler, J., Harpke, A., and Klotz, S. (2016). Dispersal traits as indicators of vegetation dynamics in long-term old-field succession. Ecol. Indic. 65, 44-54. doi: 10.1016/j.ecolind.2015.10.003

Koch, P. L., and Barnosky, A. D. (2006). Late quaternary extinctions: state of the debate. Annu. Rev. Ecol. Evol. Syst. 37, 215-250. doi: 10.1146/annurev.ecolsys.34.011802.132415

Kowarik, I. (1995). "On the role of alien species in urban flora and vegetation," in Plant Invasions-General Aspects and Special Problems, eds. P. Pysek, M. Rejmanek, and M. Wade (Amsterdam: SPB Academic Publishing), 85-103.

Kowarik, I., and von der Lippe, M. (2011). Secondary wind dispersal enhances long-distance dispersal of an invasive species in urban road corridors. NeoBiota 9, 49-70. doi: 10.3897/neobiota.9.1469

Kühn, I., and Klotz, S. (2006). Urbanization and homogenization-comparing the floras of urban and rural areas in Germany. Biol. Conserv. 127, 292-300. doi: 10.1016/j.biocon.2005.06.033

Larsen, T. H., Williams, N. M., and Kremen, C. (2005). Extinction order and altered community structure rapidly disrupt ecosystem functioning. Ecol. Lett. 8, 538-547. doi: 10.1111/j.1461-0248.2005.00749.x

Laurance, W. F., Goosem, M., and Laurance, S. G. (2009). Impacts of roads and linear clearings on tropical forests. Trends Ecol. Evol. 24, 659-669. doi: 10.1016/j.tree.2009.06.009

Leblond, M., Dussault, C., and Ouellet, J.-P. (2013). Impacts of human disturbance on large prey species: do behavioral reactions translate to fitness consequences? PLoS ONE 8:e73695. doi: 10.1371/journal.pone.0073695

Lenda, M., Knops, J. H., Skórka, P., Moron, D., and Woyciechowski, M. (2018). Cascading effects of changes in land use on the invasion of the walnut Juglans regia in forest ecosystems. J. Ecol. 106, 671-686. doi: 10.1111/1365-2745.12827

Lepczyk, C. A., Aronson, M. F. J. J., Evans, K. L., Goddard, M. A., Lerman, S. B. and MacIvor, J. S. (2017). Biodiversity in the city: fundamental questions for understanding the ecology of urban green spaces for biodiversity conservation. Bioscience 67, 799-807. doi: 10.1093/biosci/bix079

Levey, D. J., Tewksbury, J. J., and Bolker, B. M. (2008). Modelling longdistance seed dispersal in heterogeneous landscapes. J. Ecol. 96, 599-608. doi: 10.1111/j.1365-2745.2008.01401.x

Liang, Y., Li, J., Li, J., and Valimaki, S. K. (2008). Impact of urbanization on plant diversity: a case study in built-up areas of Beijing. For. Stud. China 10, 179-188. doi: $10.1007 /$ s11632-008-0036-4 
López-Bao, J. V., and González-Varo, J. P. (2011). Frugivory and spatial patterns of seed deposition by carnivorous mammals in anthropogenic landscapes: a multi-scale approach. PLOS ONE 6:e14569. doi: 10.1371/journal.pone. 0014569

Loss, S. R., Will, T., and Marra, P. P. (2015). Direct mortality of birds from anthropogenic causes. Annu. Rev. Ecol. Evol. Syst. 46, 99-120. doi: 10.1146/annurev-ecolsys-112414-054133

Lundberg, J., Andersson, E., Cleary, G., and Elmqvist, T. (2008). Linkages beyond borders: targeting spatial processes in fragmented urban landscapes. Landsc. Ecol. 23, 717-726. doi: 10.1007/s10980-008-9232-9

Machon, N., Bardin, P., Mazer, S. J., Moret, J., Godelle, B., and Austerlitz, F. (2003). Relationship between genetic structure and seed and pollen dispersal in the endangered orchid Spiranthes spiralis. New Phytol. 157, 677-687. doi: 10.1046/j.1469-8137.2003.00694.x

Mahandran, V., Murugan, C. M., Marimuthu, G., and Nathan, P. T. (2018). Seed dispersal of a tropical deciduous Mahua tree, Madhuca latifolia (Sapotaceae) exhibiting bat-fruit syndrome by pteropodid bats. Glob. Ecol. Conserv. 14:e00396. doi: 10.1016/j.gecco.2018.e00396

Manel, S., and Holderegger, R. (2013). Ten years of landscape genetics. Trends Ecol. Evol. 28, 614-621. doi: 10.1016/j.tree.2013.05.012

Marco, A., Lavergne, S., Dutoit, T., and Bertaudiere-Montes, V. (2010). From the backyard to the backcountry: how ecological and biological traits explain the escape of garden plants into mediterranean old fields. Biol. Invasions 12, 761-779. doi: 10.1007/s10530-009-9479-3

Markl, J. S., Schleuning, M., Forget, P. M., Jordano, P., Lambert, J. E., Traveset, A., et al. (2012). Meta-analysis of the effects of human disturbance on seed dispersal by animals. Conserv. Biol. 26, 1072-1081. doi: 10.1111/j.1523-1739.2012.01927.x

Martin, J. G., and Réale, D. (2008). Animal temperament and human disturbance: implications for the response of wildlife to tourism. Behav. Proc. 77, 66-72. doi: 10.1016/j.beproc.2007.06.004

Martínez, I., García, D., and Obeso, J. R. (2008). Differential seed dispersal patterns generated by a common assemblage of vertebrate frugivores in three fleshy-fruited trees. Écoscience 15, 189-199. doi: 10.2980/15-2-3096

McConkey, K. R., and Drake, D. R. (2006). Flying foxes cease to function as seed dispersers long before they become rare. Ecology 87, 271-276. doi: 10.1890/05-0386

McConkey, K. R., and Drake, D. R. (2015). Low redundancy in seed dispersal within an island frugivore community. AoB Plants 7:plv088. doi: 10.1093/aobpla/plv088

McConkey, K. R., and O'Farrill, G. (2016). Loss of seed dispersal before the loss of seed dispersers. Biol. Conserv. 201, 38-49. doi: 10.1016/j.biocon.2016.06.024

McDonnell, M. J., and Pickett, S. T. A. (1990). Ecosystem structure and function along urban-rural gradients: an unexploited opportunity for ecology. Ecology 71, 1232-1237. doi: 10.2307/1938259

McKinney, M. L. (2006). Urbanization as a major cause of biotic homogenization. Biol. Conserv. 127, 247-260. doi: 10.1016/j.biocon.2005.09.005

McKinney, M. L. (2008). Effects of urbanization on species richness: a review of plants and animals. Urban Ecosyst. 11, 161-176. doi: 10.1007/s11252-007-0045-4

Melles, S., Glenn, S., and Martin, K. (2003). Urban bird diversity and landscape complexity: species-environment associations along a multiscale habitat gradient. Ecol. Soc. 7:5. doi: 10.5751/ES-00478-070105

Mello, M. A., Marquitti, F. M., Guimarães, P. R., Kalko, E. K., Jordano, P., and de Aguiar, M. A. (2011). The missing part of seed dispersal networks: Structure and robustness of bat-fruit interactions. PLOS ONE 6, 1-10. doi: 10.1371/journal.pone.0017395

Miles, L. S., Dyer, R. J., and Verrelli, B. C. (2018). Urban hubs of connectivity: contrasting patterns of gene flow within and among cities in the western black widow spider. Proc. R. Soc. B Biol. Sci. 285:20181224. doi: $10.1098 /$ rspb.2018.1224

Mueller, J. C., Partecke, J., Hatchwell, B. J., Gaston, K. J., and Evans, K. L. (2013). Candidate gene polymorphisms for behavioural adaptations during urbanization in blackbirds. Mol. Ecol. 22, 3629-3637. doi: 10.1111/mec. 12288

Ness, J. H., Bronstein, A., Andersen, N., and Holland, J. N. (2004). Ant body size predicts dispersal distance of ant- adapted seeds: implications of small-ant invasions. Ecology 85, 1244-1250. doi: 10.1890/03-0364
Ness, J. H., Pfeffer, M., Stark, J., Guest, A., Combs, L. J., and Nathan, E. (2016). In an arid urban matrix, fragment size predicts access to frugivory and rain necessary for plant population persistence. Ecosphere 7:e01284. doi: 10.1002/ecs2.1284

Neuenkamp, L., Lewis, R. J., Koorem, K., Zobel, K., and Zobel, M. (2016). Changes in dispersal and light capturing traits explain post-abandonment community change in semi-natural grasslands. J. Veg. Sci. 27, 1222-1232. doi: $10.1111 /$ jvs. 12449

Niu, H. Y., Xing, J. J., Zhang, H. M., Wang, D., and Wang, X. R. (2018). Roads limit of seed dispersal and seedling recruitment of Quercus chenii in an urban hillside forest. Urban For. Urban Green. 30, 307-314. doi: 10.1016/j.ufug.2018.01.023

Nogales, M., Nieves, C., Illera, J. C., Padilla, D. P., and Traveset, A. (2005). Effect of native and alien vertebrate frugivores on seed viability and germination patterns of Rubia fruticosa (Rubiaceae) in the eastern Canary Islands. Funct. Ecol. 19, 429-436. doi: 10.1111/j.0269-8463.2005.00975.x

OECD (2018). Urban Population by City Size (Indicator). doi: 10.1787/b4332f92-en (Accessed 13 August, 2018).

Ossola, A., Nash, M. A., Christie, F. J., Hahs, A. K., and Livesley, S. J. (2015). Urban habitat complexity affects species richness but not environmental filtering of morphologically-diverse ants. PeerJ. 3:e1356. doi: 10.7717/peerj.1356

Overdyck, E., and Clarkson, B. D. (2012). Seed rain and soil seed banks limit native regeneration within urban forest restoration plantings in Hamilton City, New Zealand. N. Z. J. Ecol. 36, 177-190. Available online at: https:// researchcommons.waikato.ac.nz/handle/10289/7657

Overdyck, E., Clarkson, B. D., Laughlin, D. C., and Gemmill, C. E. C. (2013). Testing broadcast seeding methods to restore urban forests in the presence of seed predators. Restor. Ecol. 21, 763-769. doi: 10.1111/j.1526-100X.2012.00933.x

Ozinga, W. A., Bekker, R. M., Schaminee, J. H. J., and Van Groenendael, J. M. (2004). Dispersal potential in plant communities depends on environmental conditions. J. Ecol. 92, 767-777. doi: 10.1111/j.0022-0477.2004.00916.x

Padayachee, A. L., Irlich, U. M., Faulkner, K. T., Gaertner, M., Procheş, S., Wilson, J. R. U., et al. (2017). How do invasive species travel to and through urban environments? Biol. Invasions 19, 3557-3570. doi: 10.1007/s10530-017-1596-9

Palfi, Z., Spooner, P. G., and Robinson, W. (2017). Seed dispersal distances by ants increase in response to anthropogenic disturbances in Australian roadside environments. Front. Ecol. Evol. 5, 1-9. doi: 10.3389/fevo.2017.00132

Partecke, J., and Gwinner, E. (2007). Increased sedentariness in European Blackbirds following urbanization: a consequence of local adaptation? Ecology 88, 882-890. doi: 10.1890/06-1105

Penone, C., Machon, N., Julliard, R., and Le Viol, I. (2012). Do railway edges provide functional connectivity for plant communities in an urban context? Biol. Conserv. 148, 126-133. doi: 10.1016/j.biocon.2012.01.041

Pimm, S. L., Jenkins, C. N., Abell, R., Brooks, T. M., Gittleman, J. L., Joppa, L. N., et al. (2014). The biodiversity of species and their rates of extinction, distribution, and protection. Science 344:1246752. doi: $10.1126 /$ science. 1246752

Pizo, M. A. (1997). Seed dispersal and predation in two populations of Cabralea canjerana (Meliaceae) in the atlantic forest of southeastern Brazil. J. Trop. Ecol. 13, 559-577. doi: 10.1017/S0266467400010713

Portugal, A. B., Carvalho, F. L., de Macedo Carneiro, P. B., Rossi, S., and de Oliveira Soares, M. (2016). Increased anthropogenic pressure decreases species richness in tropical intertidal reefs. Mar. Environ. Res. 120, 44-54. doi: 10.1016/j.marenvres.2016.07.005

Preisler, H. K., Ager, A. A., and Wisdom, M. J. (2013). Analyzing animal movement patterns using potential functions. Ecosphere 4, 1-13. doi: 10.1890/ES12-00286.1

Prosser, C., Hudson, S., and Thompson, M. B. (2006). Effects of urbanization on behavior, performance, and morphology of the Garden Skink, Lampropholis guichenoti. J. Herpetol. 40, 151-159. doi: 10.1670/38-05A.1

Rebele, F. (1994). Urban ecology and special features of urban ecosystems. Glob. Ecol. Biogeogr. Lett. 4:173. doi: 10.2307/2997649

Reichard, S. H. (2010). "Inside out: invasive plants and urban environments," in Urban Ecosystem Ecology Agron Monogr. 55, eds. J. Aitkenhead-Peterson and A. Volder (Madison, WI: ASA, CSSA, SSSA), 241-251.

Renner, S. C., Suarez-Rubio, M., Wiesner, K. R., Drögemüller, C., Gockel, S., Kalko, E. K. V., et al. (2016). Using multiple landscape genetic approaches to test the validity of genetic clusters in a species characterized by an isolation-by-distance pattern. Biol. J. Linn. Soc. 118, 292-303. doi: 10.1111/bij.12737 
Richards, G. C. (1990). The spectacled flying-fox, Pteropus conspicillatus (Chiroptera: Pteropodidae), in north Queensland. diet, seed dispersal and feeding ecology.Austr. Mammal. 13,25-31

Richardson, D. M., Allsopp, N., D’Antonio, C. M., Milton, S. J., and Rejmánek, M. (2000). Plant invasions-the role of mutualism. Biol. Rev. 75, 65-93. doi: 10.1111/j.1469-185X.1999.tb00041.x

Rivkin, L. R., Santangelo, J. S., Alberti, M., Aronson, M. F. J., de Keyzer, C. W., Diamond, S. E., et al. (2018). A roadmap for urban evolutionary ecology. Perspective doi: 10.1111/eva.127. [Epub a head of print].

Robinson, G. R., and Handel, S. N. (2000). Directing spatial patterns of recruitment during an experimental urban woodland reclamation. Ecol. Appl. 10, 174-188. doi: 10.1890/1051-0761(2000)010[0174:DSPORD]2.0.CO;2

Rodríguez-Cabal, M. A., Aizen, M. A., and Novaro, A. J. (2007). Habitat fragmentation disrupts a plant-disperser mutualism in the temperate forest of South America. Biol. Conserv. 139, 195-202. doi: 10.1016/j.biocon.2007.06.014

Rolando, A., Maffei, G., Pulcher, C., and Giuso, A. (1997). Avian community structure along an urbanization gradient. Ital. J. Zool. 64, 341-349. doi: $10.1080 / 11250009709356221$

Rost, J., Pons, P., and Bas, J. M. (2012). Seed dispersal by carnivorous mammals into burnt forests: an opportunity for non-indigenous and cultivated plant species. Basic Appl. Ecol. 13, 623-630. doi: 10.1016/j.baae.2012.08.016

Rowles, A. D., and O'Dowd, D. J. (2009). New mutualism for old: indirect disruption and direct facilitation of seed dispersal following Argentine ant invasion. Oecologia 158, 709-716. doi: 10.1007/s00442-008-1171-2

Rudd, H., Vala, J., and Schaefer, V. (2002). Importance of backyard habitat in a comprehensive biodiversity conservation strategy: a connectivity analysis of urban green spaces. Restor. Ecol. 10, 368-375. doi: 10.1046/j.1526-100X.2002.02041.x

Safner, T., Miller, M. P., McRae, B. H., Fortin, M. J., and Manel, S. (2011). Comparison of Bayesian clustering and edge detection methods for inferring boundaries in landscape genetics. Int. J. Mol. Sci. 12, 865-889. doi: $10.3390 /$ ijms 12020865

Šálek, M., Drahníková, L., and Tkadlec, E. (2015). Carnivores along the naturalurban habitat gradient. Mamm. Rev. 45, 1-14. doi: 10.1111/mam.12027

Scheepens, J. F., Frei, E. S., Armbruster, G. F., and Stöcklin, J. (2012). Pollen dispersal and gene flow within and into a population of the alpine monocarpic plant Campanula thyrsoides. Ann. Bot. 110, 1479-1488. doi: $10.1093 / \mathrm{aob} / \mathrm{mcs} 131$

Schilthuizen, M. (2018). Darwin Comes to Town: How the Urban Jungle Drives Evolution. New York, NY: Picador.

Schleuning, M., Fründ, J., Klein, A. M., Abrahamczyk, S., Alarcón, R., Albrecht, M., et al. (2012). Specialization of mutualistic interaction networks decreases toward tropical latitudes. Curr. Biol. 22, 1925-1931. doi: 10.1016/j.cub.2012.08.015

Schupp, E. W. (1993). Quantity, quality and the effectiveness of seed dispersal by animals. Vegetatio 107-108, 15-29. doi: 10.1007/978-94-011-1749-4_2

Schupp, E. W., Jordano, P., and Gómez, J. M. (2017). A general framework for effectiveness concepts in mutualisms. Ecol. Lett. 20, 577-590. doi: $10.1111 /$ ele. 12764

Smith, T. B., and Bernatchez, L. (2008). Evolutionary change in human-altered environments. Mol. Ecol. 17, 1-8. doi: 10.1111/j.1365-294X.2007.03607.x

Smouse, P. E., Sork, V. L., Scofield, D. G., and Grivet, D. (2012). Using seedling and pericarp tissues to determine maternal parentage of dispersed valley oak recruits. J. Hered. 103, 250-259. doi: 10.1093/jhered/esr141

Sol, D., Maspons, J., Gonzalez-Voyer, A., Morales-Castilla, I., Garamszegi, L. Z., and Møller, A. P. (2018). Risk-taking behavior, urbanization and the pace of life in birds. Behav. Ecol. Sociobiol. 72:59. doi: 10.1007/s00265-018-2463-0

Sork, V. L. (2016). Gene flow and natural selection shape spatial patterns of genes in tree populations: implications for evolutionary processes and applications. Evol. Appl. 9, 291-310. doi: 10.1111/eva.12316

Srbek-Araujo, A. C., Gnocchi, A. P., Guimarães, L. J., and Roper, J. J. (2017). Defaunation as a trigger for the additional loss of plant species in fragmented landscapes: considerations on the state of Espírito Santo, southeastern Brazil. Rodriguesia 68, 2001-2017. doi: 10.1590/2175-7860201768530

Steele, M. A., Bugdal, M., Yuan, A., Bartlow, A., Buzalewski, J., Lichti, N., et al. (2011). Cache placement, pilfering, and a recovery advantage in a seeddispersing rodent: could predation of scatter hoarders contribute to seedling establishment? Acta Oecol. 37, 554-560. doi: 10.1016/j.actao.2011.05.002
Steele, M. A., Rompré, G., Stratford, J. A., Zhang, H., Suchocki, M., and Marino, S. (2015). Scatterhoarding rodents favor higher predation risks for cache sites: the potential for predators to influence the seed dispersal process. Integr. Zool. 10, 257-266. doi: 10.1111/1749-4877.12134

Suárez-Esteban, A., Delibes, M., and Fedriani, J. M. (2013). Barriers or corridors? the overlooked role of unpaved roads in endozoochorous seed dispersal. J. Appl. Ecol. 50, 767-774. doi: 10.1111/1365-2664.12080

Sundriyal, R. C., and Sharma, E. (1996). Anthropogenic pressure on tree structure and biomass in the temperate forest of Mamlay watershed in Sikkim. For. Ecol. Manage. 81, 113-134. doi: 10.1016/0378-1127(95)03657-1

Tan, K. H., Zubaid, A., and Kunz, T. H. (2000). Fruit dispersal by the lesser dog-faced fruit bat, Cynopterus brachyotis (Muller) (Chiroptera: Pteropodidae). Malayan Nat. J. 54, 57-62. Available online at: https://www.cabdirect.org/ cabdirect/abstract/20013043027

Taylor, P. D., Fahrig, L., Henein, K., and Merriam, G. (1993). Connectivity is a vital element of landscape structure. Oikos 68:571. doi: 10.2307/3544927

Thompson, B., and McLachlan, S. (2007). The effects of urbanization on ant communities and myrmecochory in Manitoba, Canada. Urban Ecosyst. 10, 43-52. doi: 10.1007/s11252-006-0013-4

Thompson, D. C., and Thompson, P. S. (1980). Food habits and caching behavior of urban grey squirrels. Can. J. Zool. 58, 701-710. doi: 10.1139/z80-101

Thompson, K., and McCarthy, M. A. (2008). Traits of British alien and native urban plants. J. Ecol. 96, 853-859. doi: 10.1111/j.1365-2745.2008.01383.x

Thompson, K. A., Renaudin, M., and Johnson, M. T. (2016). Urbanization drives the evolution of parallel clines in plant populations. Proc. Biol. Sci. 283:20162180. doi: $10.1098 /$ rspb.2016.2180

Timóteo, S., Correia, M., Rodríguez-Echeverría, S., Freitas, H., and Heleno, R. (2018). Multilayer networks reveal the spatial structure of seed-dispersal interactions across the Great Rift landscapes. Nat. Commun. 9, 1-11. doi: 10.13140/RG.2.2.17399.52640

Tracey, J. A., Zhu, J., Boydston, E., Lyren, L., Fisher, R. N., and Crooks, K. R. (2013). Mapping behavioral lansdcapes for animal movement: a finite mixture modeling approach. Ecol. Appl. 23, 654-669. doi: 10.1890/12-0687.1

Tregidgo, D. J., Barlow, J., Pompeu, P. S., de Almeida Rocha, M., and Parry, L. (2017). Rainforest metropolis casts $1,000-\mathrm{km}$ defaunation shadow. Proc. Natl. Acad. Sci. 114, 8655-8659. doi: 10.1073/pnas.1614499114

Tryjanowski, P., Sparks, T. H., Kuzniak, S., Czechowski, P., and Jerzak, L. (2013). Bird migration advances more strongly in urban environments. PLOS ONE 8:e63482. doi: 10.1371/journal.pone.0063482

Tsang, A. C. W., and Corlett, R. T. (2005). Reproductive biology of the Ilex species (Aquifoliaceae) in Hong Kong, China. Can. J. Bot. 83, 1645-1654. doi: 10.1139/b05-131

Tsuji, Y., Tatewaki, T., and Kanda, E. (2011). Endozoochorous seed dispersal by sympatric mustelids, Martes melampus and Mustela itatsi, in western Tokyo, central Japan. Mamm. Biol. Zeitschrift für Säugetierkd. 76, 628-633. doi: 10.1016/j.mambio.2011.01.002

Tucker, M. A., Böhning-Gaese, K., Fagan, W. F., Fryxell, J. M., Van Moorter, B., Alberts, S. C., et al. (2018). Moving in the anthropocene: global reductions in terrestrial mammalian movements. Science 359, 466-469. doi: $10.1126 /$ science.aam 9712

Twyford, A. D., Kidner, C. A., and Ennos, R. A. (2014). Genetic differentiation and species cohesion in two widespread central american begonia species. Heredity 112, 382-390. doi: 10.1038/hdy.2013.116

Tzoulas, K., Korpela, K., Venn, S., Yli-Pelkonen, V., Kazmierczak, A., Niemela, J., et al. (2007). Promoting ecosystem and human health in urban areas using green infrastructure: a literature review. Landsc. Urban Plan. 81, 167-178. doi: 10.1016/j.landurbplan.2007.02.001

Uchida, K., Suzuki, K., Shimamoto, T., Yanagawa, H., and Koizumi, I. (2016). Seasonal variation of flight initiation distance in Eurasian red squirrels in urban versus rural habitat. J. Zool. 298, 225-231. doi: 10.1111/ jzo.12306

Uriarte, M., Anciães, M., Da Silva, M. T., Rubim, P., Johnson, E., Bruna, E. M., et al. (2011). Disentangling the drivers of reduced long-distance seed dispersal by birds in an experimentally fragmented landscape. Ecology 92, 924-937. doi: 10.1890/10-0709.1

van Leeuwen, C. H. A. (2018). Internal and external dispersal of plants by animals: an aquatic perspective on alien interference. Front. Plant Sci. 9:153. doi: $10.3389 /$ fpls.2018.00153 
Vander Wall, S. B., and Longland, W. S. (2004). Diplochory: Are two seed dispersers better than one? Trends Ecol. Evol. 19, 155-161. doi: 10.1016/j.tree.2003.12.004

Vázquez, D. P., Blüthgen, N., Cagnolo, L., and Chacoff, N. P. (2009). Uniting pattern and process in plant-animal mutualistic networks: a review. Ann. Bot. 103, 1445-1457. doi: 10.1093/aob/mcp057

Vitousek, P. M., Mooney, H. A., Lubchenco, J., and Melillo, J. M. (2008). "Human domination of earth's ecosystems," in Urban Ecology (Boston, MA: Springer US), 3-13.

von der Lippe, M., Bullock, J. M., Kowarik, I., Knopp, T., and Wichmann, M. (2013). Human-mediated dispersal of seeds by the airflow of vehicles. PLOS ONE 8, 1-10. doi: 10.1371/annotation/50f98e02-214c-4314-b053-ca272101ead1

von der Lippe, M., and Kowarik, I. (2008). Do cities export biodiversity? traffic as dispersal vector across urban-rural gradients. Divers. Distrib. 14, 18-25. doi: 10.1111/j.1472-4642.2007.00401.x

von der Lippe, M., and Kowarik, I. (2012). Interactions between propagule pressure and seed traits shape human-mediated seed dispersal along roads. Perspect. Plant Ecol. Evol. Syst. 14, 123-130. doi: 10.1016/j.ppees.2011.09.006

Warren, R. J., Pearson, S. M., Henry, S., Rossouw, K., Love, J. P., Olejniczak, M. J., et al. (2015). Cryptic indirect effects of exurban edges on a woodland community. Ecosphere 6, 1-13. doi: 10.1890/ES15-00318.1

Weaver, M., Gao, S., and McGraw, K. J. (2018). Circulating corticosterone levels vary during exposure to anthropogenic stimuli and show weak correlation with behavior across an urban gradient in house finches (Haemorhous mexicanus). Gen. Comp. Endocrinol. 266, 52-59. doi: 10.1016/j.ygcen.2018.04.017

Westcott, D. A., and Graham, D. L. (2000). Patterns of movement and seed dispersal of a tropical frugivore. Oecologia 122, 249-257. doi: 10.1007/PL00008853

Wichmann, M. C., Alexander, M. J., Soons, M. B., Galsworthy, S., Dunne, L., Gould, R., et al. (2009). Human-mediated dispersal of seeds over long distances. Proc. R. Soc. B Biol. Sci. 276, 523-532. doi: 10.1098/rspb.2008.1131

Williams, N. S. G., Morgan, J. W., McDonnell, M. J., and Mccarthy, M. A. (2005). Plant traits and local extinctions in natural grasslands along an urban-rural gradient. J. Ecol. 93, 1203-1213. doi: 10.1111/j.1365-2745.2005 01039.x

Wright, S. J. (2005). Tropical forests in a changing environment. Trends Ecol. Evol. 20, 553-560. doi: 10.1016/j.tree.2005.07.009

Wunderle, J. M. (1997). The role of animal seed dispersal in accelerating native forest regeneration on degraded tropical lands. For. Ecol. Manage. 99, 223-235. doi: 10.1016/S0378-1127(97)00208-9

Yakub, M., and Tiffin, P. (2017). Living in the city: urban environments shape the evolution of a native annual plant. Glob. Chang. Biol. 23, 2082-2089. doi: $10.1111 /$ gcb.13528

Young, H. S., McCauley, D. J., Galetti, M., and Dirzo, R. (2016). Patterns, causes, and consequences of Anthropocene defaunation. Annu. Rev. Ecol. Evol. Syst. 47, 333-358. doi: 10.1146/annurev-ecolsys-11241 4-054142

Zapata, V. M., Robledano, F., Ramos, V., and Martínez-López, V. (2014). Birdmediated seed dispersal of fleshy fruits of mediterranean shrubs in semiarid forest patches: the role of Pinus halepensis Miller trees as seed receptors. Plant Ecol. 215, 1337-1350. doi: 10.1007/s11258-014-0391-2

Zucaratto, R., and dos Santos Pires, A. (2015). Local extinction of an important seed disperser does not modify the spatial distribution of the endemic palm Astrocaryum aculeatissimum (Schott) Burret (Arecaceae). Acta Bot. Brasilica 29, 244-250. doi: 10.1590/0102-33062015abb0008

Conflict of Interest Statement: The authors declare that the research was conducted in the absence of any commercial or financial relationships that could be construed as a potential conflict of interest.

Copyright (C) 2019 Gelmi-Candusso and Hämäläinen. This is an open-access article distributed under the terms of the Creative Commons Attribution License (CC BY).

The use, distribution or reproduction in other forums is permitted, provided the original author(s) and the copyright owner(s) are credited and that the original publication in this journal is cited, in accordance with accepted academic practice. No use, distribution or reproduction is permitted which does not comply with these terms. 


\section{GLOSSARY}

Anemochory, anemochorous

Anthropogenic disturbance

Built environment

Diaspore

Ecosystem service

Ecosystem dynamics

Elaiosome

Endozoochory, endozoochorous

Exurban

Functional replacement

Heat island effect

Myrmecochory, myrmecochorous

Natural environment

Peri-urban

Seed shadow

Soil seed bank

Synzoochory, synzoochorous

Urbanization
Wind-mediated dispersal. Plants that are primarily dispersed by wind are referred to as anemochorous plants

Human impact on the environment, such as vegetation clearing, fragmentation through construction, human presence, or the introduction of invasive species

Aspects of the surroundings that are built by humans, including all forms of buildings (housing, industrial, commercial) and infrastructure that supports human activity (e.g., transportation networks)

The dispersing unit of a plant, consisting of the seed and associated tissues that facilitate dispersal, such as the elaiosome

Functions performed by ecosystems, that are beneficial for humans in some way

Ecosystem processes that change over time, such as plant regeneration and turnover, gene flow, resource abundance and distribution

Nutrient-rich structure attached to a seed that attracts seed-dispersing animals. The tissues are typically oily and protein-rich and attract ants

Seed dispersal through ingestion by animals, followed by regurgitation or defecation of viable seeds. Plants that are primarily dispersed by animal ingestion and defecation are referred to as endozochorous plants

Commuter towns or neighborhoods located in the outskirts of cities, typically beyond the suburbs immediately connected to the city Replacement of the ecosystem function of one species by another species in a way that maintains the ecosystem function Urban areas form heat islands because heat is generated and trapped in the physical urban environment, making urban areas warmer than the surrounding landscape

Ant-mediated dispersal

Ecological units without much human interference, considered natural systems.

Areas immediately surrounding urban areas, urban periphery

"the spatial pattern of seed distribution relative to parent trees and other conspecifics; it results from the process of seed dispersal and represents the starting template for plant regeneration" (Jordano and Godoy, 2002)

The quantity of dormant but viable seeds found in the soil or substrate

Seed dispersal through deliberate transportation of seeds by animals, such as for the purpose of caching

The process of an area becoming urbanized, taking characteristics of a city, an inhabited place of greater size, population, or importance than a town or village. 